\title{
ECONOMICS
}

\section{Deflation Forces and Inequality}

\author{
Rod TYERS \\ Business School \\ University of Western Australia, \\ Research School of Economics, \\ Centre for Applied Macroeconomic Analysis (CAMA) \\ Australian National University
}

Yixiao ZHOU

School of Economics and Finance

Curtin Business School

Curtin University 


\title{
Deflation Forces and Inequality*
}

\author{
Rod TYERS \\ Business School \\ University of Western Australia, \\ Research School of Economics, \\ Centre for Applied Macroeconomic Analysis (CAMA) \\ Australian National University \\ Yixiao ZHOU \\ School of Economics and Finance \\ Curtin Business School \\ Curtin University
}

First Draft March 2018

Key words:

Inflation, deflation, productivity, automation, income distribution, tax, transfers, general equilibrium analysis

JEL Codes:

D33, E52, J11, O33

Author best contact details:

Rod Tyers

Winthrop Professor of Economics

UWA Business School

Crawley, WA 6009

Australia

rod.tyers@uwa.edu.au

** Thanks are due to Grace Taylor at the Reserve Bank of Australia for assistance with data. The model used in the paper is solved using the Gempack software. 


\title{
Deflation Forces and Inequality
}

\begin{abstract}
Proximity to short yield zero lower bounds has challenged the inflation targeting central banks of the advanced regions. Central to this development are three-decade declining trends in long yields and underlying real, equilibrium interest rates that have flattened yield curves, restricting "normalisation" and adding deflationary pressure by boosting demand for portfolio money. Inflationary forces, such as fiscal deficits, industrial protection and resurgent regional growth, have proved comparatively weak. In this paper global modelling is used to show that key deflationary forces in these regions include automation, the race to the bottom in capital taxation and immigration. Each is shown to redistribute income so as to expand the welfare gap between the low-skilled and capital owners by 2.5 to 3.5 per cent per year. The high saving rates of capital owners depress real equilibrium rates and their expanding portfolios demand monetary expansion. These forces ensure that the challenges of macro stabilisation and distributional policy making are both intertwined and urgent.
\end{abstract}

\section{Introduction}

Inflation rates in the advanced economies have been on a declining trend since the 1980s, diving more steeply in recent years. ${ }^{1}$ Non-coincidentally, a similar declining pattern can be observed in nominal bond yields at all maturities. ${ }^{2}$ The major central banks are now perceived to be less equipped to offset deflationary forces due to the proximity of the "zero lower bound" (ZLB) on yields in short maturity asset markets ${ }^{3}$ and because of the associated declining trend in the "natural", or equilibrium, real rate of interest at the global level. ${ }^{4} \mathrm{~A}$ consequence of these trends has been the transition by these central banks to unconventional monetary policy (UMP), the downsides of which stem from expected inflation that is below central bank targets, along with widening income and wealth disparities, the coincidence of firm “zombification” and low productivity growth, trade tensions due to associated exchange

\footnotetext{
${ }^{1}$ The recent decline in inflation is not simply explained by a fall in commodity prices. The decline in energy prices since 2014 has contributed as a deflationary force but it does not explain the fall in "core” inflation, which excludes energy and food, in both the US and Europe (Demary and Hüther 2015, Brainard 2017).

2 The rate of inflation in Europe, Japan and North America has been seen as undesirably low (Rosengren 2014, Blitz and MacKenzie 2017, Conti et al. 2017, The Economist 2017c) and the duo of low inflation and low interest rates is seen as having unfortunate direct consequences (Fessenden 2017, Financial Times 2017) as well as limiting the capacity of central banks to respond to future negative shocks (Summers 2017).

${ }^{3}$ The ZLB arises because of the perception that no-one would choose to hold negative yielding bonds when zero-yielding cash is available as an alternative. Negative yields arise in practice mainly because the holding of cash is not costless (Rognlie 2016).

${ }^{4}$ Laubach and Williams (2003) define the equilibrium real rate of interest, which is monitored by the Federal Reserve Bank of San Francisco, and recent discussions of its declining trend include that by Rachel and Smith (2015), Williams (2015) and Holston et al. (2018).
} 
rate movements and rising risk due to net leverage. ${ }^{5}$ This begs the question as to what are the deflationary forces that central banks are fighting against that have recently been so overwhelming.

A policy bias against deflation goes back at least to Keynes (1950: 10, and 2007: 16), whose concerns about its consequences, relative to those of inflation included unemployment due to nominal wage rigidity, the discouragement of borrowing for investment and the encouragement of money "hoarding”, or increased holding of portfolio money at the expense of productive assets (Bagus 2015). The prospect of deflation is always associated with a lack of perceived capacity on the part of central banks to accommodate money demand, yet we assess that there are increasingly prominent deflationary forces in the global economy, the power of which has not been consistently assessed. We seek to compare their impacts by using a global model to decompose the money demand effects of each of these forces under conditions where inflation expectations are anchored at a zero target.

Inflationary (deflationary) forces include shifts toward optimism (pessimism) about future real disposable income and their consequences for consumption and investment expenditure and government deficits. ${ }^{6}$ Deflationary forces also include the credibility of central bank inflation targeting, with short rates near the ZLB. Here we imagine that inflation expectations are anchored at central bank targets and classify deflationary forces as those that raise the demand for money relative to goods under these circumstances. While there are likely many sources of deflation in the advanced economies, we focus on three that have rising prominence in the economic policy literature, namely automation, the race to the bottom in capital income taxation and immigration. ${ }^{7}$ Automation and immigration flows suppress real wage growth and all three forces have the common feature that they deliver greater returns to high-saving capital owners, raise collective saving relative to investment

\footnotetext{
${ }^{5}$ The literature on UMP and its consequences is now large. There is no doubt that UMP helped restore liquidity and capitalization to the banks and other financial institutions (Fawley and Neely 2013, Chodorow-Reich 2015). Yet its downsides have been linked to the negative feedback loop that sees low yields raise portfolio money holding, demanding monetary expansions via UMP that have further reduced yields. See Burns et al. (2014), BIS (2017), Gugliano (2017), Watling (2017) and Williams (2015) for more discussion.

${ }^{6}$ Increased protection across trading partners is also collectively inflationary. This is a force that may become stronger in future, possibly even offsetting those considered in this paper.

${ }^{7}$ One deflationary force that we neglect is the modern prominence of value chains and the rising significance in the advanced economies of external value added. These have been deflationary because transaction volumes include intermediates, the trade in which also requires liquidity, and since these networks constrain costs (Auer et al. 2017). We neglect this force here because it appears to have had most effect in the decade prior to the GFC but its effects have abated since.
} 
demand and so reduce the Wicksellian (1898) real equilibrium interest rate in the comparatively integrated global financial capital market. ${ }^{8}$

To analyse these effects we employ a special purpose macro model of the global economy on six regions that parameterizes the global integration of financial and product markets via asset and product differentiation and that incorporates expectations over consumer and GDP price indices. Money demand in each region is driven by product transactions, financial transactions and portfolio rebalancing in response to real long yields, which we regard as representing the opportunity cost of money holding. ${ }^{9}$ In response to the three deflation forces, departures from a zero growth, zero inflation growth path, with inflation expectations anchored at zero, are then recorded.

Our results suggest that, by redistributing income to high-saving households globally, sufficient to grow the gap between the real disposable income of capital owning relative to working households by 2.5 to 3.5 per cent per year, and thereby raising global saving, the three prospective forces reduce real long interest rate levels by around two per cent per year. ${ }^{10}$ The monetary expansions then required to keep pace with these forces alone raise money demand by between 2.2 and 3.2 per cent per year. The effectiveness of macroeconomic policy in stabilising performance around growth trends in the advanced economies is thus shown to depend on how governments address the distributional effects of these forces.

We briefly note the stylised facts in Section 2. The modelling undertaken is summarised in Section 3 with fine details relegated to an appendix. The results obtained are discussed in Section 4 while Section 5 concludes.

\section{The Stylised Facts}

Key trends interlink macroeconomic with distributional performance in the advanced economies. We take these in turn.

\footnotetext{
${ }^{8}$ Immigration is not among the determinants of rate decline considered by Holston et al. (2018) but there is a growing literature on its macroeconomic impacts that includes Kirby and Riley (2006), Nickell (2007), Goodhart and Pradhan (2017) and Harris et al. (2018). Recent popular interest is indicated by The Guardian (2018).

${ }^{9}$ Financial transactions have significant effects on demand for liquidity, following Baumol (1952) and Tobin (1956) and capital owners are the largest holders of precautionary/portfolio money (Ragot 2014, Mena and Tirelli 2017).

${ }^{10}$ With real long maturity yields currently of the order
} 


\subsection{Macro and Financial Performance:}

With the passing of real anchors in the early 1970s a period of financial volatility ensued with monetary policy targets in the advanced economies transitioning from gold and exchange rates through money aggregates to inflation rates. ${ }^{11}$ Throughout this period most central bank mandates also attached weight to measures of real output and unemployment but their focus has been on a target range for inflation. ${ }^{12}$ As indicated in Figure 1, with the transition to inflation targeting, consumer price index (CPI) inflation rates in these advanced economies stabilised in the 1990s, though they have trended even lower very recently. Indeed, the corresponding rates of producer price inflation, while historically more volatile, show a marked dip into deflation since 2014. With this has come resurgent employment growth but with the notable absence of wage inflation.

At the same time the declining trend in government bond yields, both of short and long maturity, has been dramatic and continuous, as shown in Figure $2{ }^{13}$ This is notwithstanding the very substantial fiscal deficits, which are larger relative to GDP than the advanced economies' GDP growth rates. The associated rising trend in gross sovereign debt shown in Figure 3 might otherwise be expected to drive up borrowing costs. The most recent estimates of the underlying real equilibrium interest rate by Holston et al. (2018), which adjust for fiscal balance and full employment at the country level, are shown in Figure 4. These have declined correspondingly and closely with inflation adjusted long nominal yields.

The coincidence of falling government borrowing rates and continuing high fiscal deficits suggests a surge in the global demand for bonds issued by advanced country governments, and particularly, for those issued in the US. Prior to the GFC the culprits for this were the high-saving Asian economies (Arora et al. 2015) but, since then, the demand has been spurred by central bank buying of long-maturity assets following transitions to UMP in Japan then the US and the UK, and finally, in continental Europe. This triggered wider private interest in long maturity government (and, more recently in European private) debt, leading

\footnotetext{
${ }^{11}$ In the developing world monetary policies have been dominantly focused on exchange rates against such currencies as the USD, though the IMF has been advising developing countries to transition to inflation targeting since the 1990s (Masson 1997) and increasing numbers are now adopting inflation targeting (Amato and Gerlach 2002). As in Australia, this allows uncontroversial exchange rate movements against the USD.

12 This is formalized in the widely discussed Taylor Rule (Taylor 1993), though such formality is shunned by central banks in favour of discretion.

${ }^{13}$ Note the brief inversion of Australia's yield curve in the lead-up to the GFC, due to the inflationary effects of the boom in Chinese commodity imports and the Reserve Bank of Australia's preference to see the exchange rate appreciate rather than to have it cause domestic inflation.
} 
to what has been described as a "bond bubble” (Krishnamurthy and Vissing-Jorgensen 2012, Maley 2016, Price 2016).

\subsection{Income Distribution}

That inequality has risen across the OECD countries since the 1960s is clear from Figure 5. We note also that, at least for some OECD countries, real net national product per capita has been stagnant since the 2005. This is clear from Figure 6 and, combined with the evidence from the previous figure that inequality has increased it suggests that these countries' poorer households have suffered declining welfare in this period. Further light is shed by the associated trends in total factor productivity (TFP), shown in Figure 7. These, also, show a transition around 2005 to stagnant productivity throughout the OECD. Changes in the "choice of technique" that have disadvantaged low-skill workers have also been occurring for decades. These changes are indicated by declining low-skill labour shares of total value added, shown in Figure 8. This declining trend is also generic across the OECD, though it is shown here for the US. It is the subject of a substantial literature of its own, with conclusions that divide responsibility between automation on the one hand and outsourcing and trade on the other. ${ }^{14}$

To add to this there is the succession of declines in advanced region tax rates on capital income (Broadman 2017). These exacerbate the inequality effects mentioned above but, further, they (and their prior anticipation) draw in investment from the rest of the world to lower-taxing economies, which temporarily appreciate exchange rates causing a complementary deflation force. A further change that has influenced performance and inequality in the advanced economies over these decades is immigration from poorer regions. The contributions of migrants to population changes are shown in Figure 9 to have been substantial, particularly in Australia. Since immigration advantages capital owners most and low-skill workers least, it has clearly contributed to the rises in inequality observed in Figure 5. The contribution this makes to greater saving and lower opportunity costs of holding money is then complemented by the acceleration in labour supply growth that suppresses real wage rates and impairs worker conditions, also contributing to deflation, via reduced production costs. ${ }^{15}$

\footnotetext{
${ }^{14}$ See Onaran et al. (2011), Gozgor and Ranjan (2017), Tyers and Zhou (2017), and Zhou and Tyers (2017).

${ }^{15}$ See Kirby and Riley (2006), Bentolila (2007), Blanchflower (2007), Nickell (2007) and Nickell and Saleheen (2015).
} 


\section{Modelling Deflationary and Distributional Forces}

To obtain an assessment of the key deflationary forces, we adapt a model of the global macro-economy, including in it multiple households and trade in intermediate inputs, so as to capture the deflationary forces that operate, at least in part, through changes in inequality. ${ }^{16}$ We use the model to simulate the effects of the three main deflationary forces that we believe are likely to be sustained or to strengthen in the future.

\subsection{The Model}

A multi-region general equilibrium structure is used that centres on the global financial capital market. It is assumed that the financial products of each region are differentiated and that portfolio managers assign new net saving across regions so as to maximise expected portfolio returns given this differentiation. Although there is a tendency for financial flows to move the global economy toward uncovered interest parity, in the length of run considered asset differentiation leaves this process incomplete. At the same time, expected rates of return depart from regional bond yields, the latter reflecting short run equilibria in regional financial markets, as between savers, indebted governments and investors.

Production technology is structured so as to enable factor bias shocks to occur without changing total factor productivity, and vice versa, so as to capture the factor bias associated with automation and outsourcing. In each of six regions, three households are defined based on factor income (low-skilled, skilled and capital-owning) and these have separate income transfers from governments and separate consumption behaviour.

\section{Global financial markets}

Each region's financial market is represented as the market for domestic long maturity assets. Purchasers of these assets are assumed to respond to changes in an expected rate of return on installed domestic capital, which is net of depreciation and capital tax and adjusted for sovereign risk. This rate of return is inversely proportional to the stock of utilized regional capital and its expected future value is first adjusted by a sovereign risk factor and then embedded in an interest parity condition that provides for incomplete arbitrage. Finally, a sovereign risk factor is added to reflect that deteriorating fiscal balances cause investment to be less attractive. The domestic demand for investment financing then depends on the ratio of the expected real rate of return on installed capital, which is defined as after capital income

\footnotetext{
${ }^{16}$ The model is a blend of the macro models used by Tyers (2015a and 2015b, 2016) and the distributional models used by Tyers and Zhou (2017) and Zhou and Tyers (2017).
} 
tax, and the real long bond yield that clears the domestic financial market, $r{ }^{17}$ Since the numerator indicates the market value of domestic assets and the denominator the cost of financing their replacement, this is in the tradition of Tobin's Q.

This investment demand is then matched in each region by a supply of saving that incorporates contributions from all regional households and governments. Here the modelling incorporates explicit portfolios of assets from all regions. Data on regional saving and investment is first combined with that on international financial flows to construct an initial matrix to allocate total domestic saving in each region to investment across all the regions. From this is derived a corresponding matrix of initial shares of region $i$ 's net (private and government) saving that are allocated to the local savings supply that finances investment in region $j, i_{i j}^{S 0}$. When the model is shocked, the new shares are calculated so as to favour investment in regions, $j$, whose real yields are boosted by the shock. Since these are portfolio investments, the real rate of return available in each region is assumed to be the domestic market clearing yield, $r$.

Region $i$ 's portfolio manager allocates the proportion $i_{i j}^{S}$ of its annual (private plus government) saving to new investments in regions $j$, such that $\sum_{j} i_{i j}^{S}=1 .{ }^{18}$ Because the newly issued equity is differentiated across regions based on un-modelled and unobserved regionspecific properties, their services are combined via a constant elasticity of substitution (CES) function specific to each regional portfolio manager. Thus, region $i$ 's household portfolio management problem is to choose the shares, $i_{i j}^{S}$, of its private saving net of any government deficit, $S_{i}^{D}=S_{i}^{P}+T^{D}+T^{I}-G$, which are to be allocated to the assets of region $j$ so as to maximise a CES composite representing the value of the services yielded by these assets:

$$
\max _{i_{i j}^{S}} U_{i}^{F}=S_{i}^{D}\left[\sum_{j} \alpha_{i j}\left(i_{i j}^{S}\right)^{-\rho_{i}}\right]^{-\frac{1}{\rho_{i}}} \text { such that } \sum_{j} i_{i j}^{S}=1 \text {. }
$$

Here $\alpha_{i j}$ is a parameter that indicates the benefit to flow from region $i$ 's investment in region $j$. The CES parameter, $\rho_{i}$, reflects the preparedness of region $i$ 's household to substitute between the assets it holds. To induce rebalancing in response to changes in rates of return

\footnotetext{
${ }^{17}$ Since firms do not incur tax when issuing stock or bonds, no taxation is applied in the denominator.

${ }^{18}$ The manager does not re-optimise over total holdings every year. This is because the model is deterministic and risk is incorporated only via exogenous premia. The motivations for continuous short run rebalancing, other than the arrival of new saving, are therefore not represented.
} 
the $\alpha_{i j}$ s are made dependent on ratios of after-tax yields in destination regions, $j$, and the home region, $i$, via: ${ }^{19}$

$$
\alpha_{i j}=\beta_{i j}\left[\frac{r_{j}\left(1-t_{j}^{K}\right)}{r_{i}\left(1-t_{i}^{K}\right)}\right]^{\lambda_{i}} \quad \forall i, j, \quad \lambda_{i}>0 \quad \forall i
$$

Here, $t_{i}^{K}$ is the rate of capital income tax rate in region $i$. This relationship indicates the responsiveness of portfolio preferences to yields, via the (return chasing) elasticity $\lambda_{i}$. Region $i$ 's elasticity of substitution between the bonds of different regions is $\sigma_{i}^{I}=\lambda_{i} /\left(1+\rho_{i}\right)>0$, which has two elements. The return-chasing behaviour of region $i$ 's household $\left(\lambda_{i}\right)$ and the imperfect substitutability of regional bonds, and therefore the sluggishness of portfolio rebalancing $\left(\rho_{i}\right)$. For the purposes of this analysis the values of $\sigma_{i}^{I}$ are seen as indicating the extent of each region's integration with global financial markets. The optimal share of the net domestic saving of region $i$ that is allocated to assets in region $j$ then follows from the solution, which is readily calibrated from available data, as discussed in the appendix.

Next we characterize the regional money market equilibrium. Within each region the demand for money is driven by a "cash in advance” constraint. For any one household, home money is held in a portfolio with long maturity bonds, which are claims over physical capital, combined with home and foreign long maturity government debt, and so the opportunity cost of holding money is the long maturity yield. The cash-in-advance constraint is assumed to generate transactions demand for home money across all components of gross (including intermediate) output. This effect is here augmented by the real purchasing power of financial wealth, to account for the observed dominance of financial transactions over money demand. ${ }^{20}$ The opportunity cost of holding home money is set at the nominal after-tax yield on home long term bonds. ${ }^{21}$ Real money balances are measured in terms of purchasing power over home products at the GDP price, $P^{Y}$.

\footnotetext{
${ }^{19}$ Note that region $i$ 's market bond yield, $r_{i}$, is determined concurrently and indicates the replacement cost of capital in region $i$ and therefore the opportunity cost for region $i$ 's household of investment in region $j$.

20 The inclusion of financial wealth in the money demand equation follows Ragot (2014) and Mena and Tirelli (2017), who incorporate Baumol (1952) - Tobin (1956) behaviour.

${ }^{21}$ Thus, it is assumed here that the opportunity cost of holding money is measured by the long bond yield, which is the dominant determinant of non-money portfolio yields. Short rates, at least as they have a role in conventional monetary policy, are here embedded in the determination of the monetary base. While housing investment can be sensitive to short rates in economies where most mortgage contracts have variable rates, the
} 


$$
m_{i}^{D}=a_{i}^{M D}\left(y_{i}\right)^{\varepsilon_{i}^{M Y}}\left(w_{i}^{F}\right)^{\varepsilon_{i}^{M W}}\left(\frac{r_{i}\left(1+\pi_{i}^{e}\right)}{\tau_{i}^{K}}\right)^{-\varepsilon_{i}^{M R}}=\frac{M_{i}^{S}}{P_{i}^{Y}}=\frac{\mu_{i} M_{i}^{B}}{P_{i}^{Y}}
$$

For region $i, y_{i}$ is real, regional gross output, as distinct from real GDP since intermediates are transacted as well as goods and services entering final demand. Real financial wealth is $w_{i}^{F}$, $\tau_{i}^{K}$ is the power of the capital income tax rate in region $i$ and $\pi_{i}^{e}$ is the expected inflation rate of the consumer price level, $P^{C}$, defined as a CES aggregate of home and imported consumer prices. Real financial wealth or assets, $w^{F}$, is represented as the present value of an infinite stream of real dividends that are equal to after-tax returns on the capital stock, at the expected real rate of return on installed capital, $r^{c e}$, discounted at the current real financing rate, $r$. A price adjustment is also made for relative inflation or deflation of capital goods prices, which raise or lower the purchasing power of financial wealth over home products.

$$
W_{i}^{F}=\frac{r_{i}^{c e}\left(1-t_{i}^{K}\right)\left(P_{i}^{K} / P_{i}^{Y}\right) K}{r_{i}} .
$$

The last three decades have exhibited advanced region asset price inflation that has exceeded that in goods, for the US by at least six percentage points per year on average, ${ }^{22}$ suggesting a rising path of this ratio. This comparative growth in financial wealth is due to the many determinants of wealth inequality, including the forces discussed in this paper.

On the supply side of the money market, the proportion of expansions that occur via the purchase of long maturity assets (UMP) is parameterised. Conventional expansions directly affect the money supply while UMP expansions affect both it and the long end of the yield curve. UMP expansions raise home long maturity asset prices and lower long yields, causing imperfect spill-overs due to global arbitrage that is only partially constrained by asset differentiation. $^{23}$

Regional financial market clearance requires that the home financial market in each region clears separately and this implies global financial market clearance. For region $i$, the nominal

assumption that investment financing depends on the long maturity market is a simplifying abstraction in this global analysis.

${ }^{22}$ This is readily concluded from a comparison of the path of a broad index of stock prices, such as the Wilshire Capital Price Index, and the US CPI, since 1990.

${ }^{23}$ By contrast, conventional monetary policy involves trade in short term instruments which has no direct impact on the market for long term bonds. Short rates are therefore not modelled explicitly, rather the monetary base in each region is determined as endogenous to the target of monetary policy and an exogenous parameter determines the share of any change in the monetary base that takes the form of long asset balance sheet expansion. 
value of domestic investment, $I_{i}^{D}$, from (5), represents the sum total of all domestic long bond issues. This is then equated with demand for those bonds from home and foreign (net private and government) savings, along with demands for home long bonds that arise from the "quantitative easing" components of monetary expansions by both home and foreign central banks.

Financial balance then requires that total investment spending in region $i$, in $i$ 's local currency, is equated with the total supply of financing directed from all represented regions:

$$
I_{i}^{D}=\sum_{j}\left(\left[i_{j i}^{S} S_{j}^{D}+\theta_{j i}^{Q E} S_{j}^{Q E} \Delta M_{j}^{B}\right] \frac{E_{j}}{E_{i}}\right), \quad \forall i,
$$

where $E_{i}$ is the nominal exchange rate of region $i$ relative to the US\$, which is the numeraire in the model $\left(E_{U S}=1\right)$. The "quantitative easing" component of the current period's expansion of the monetary base by region $j$ 's central bank, $s_{j}^{Q E}$, and the share of this expansion that takes the form of acquisitions of region $i$ 's long bonds, $\theta_{j i}^{Q E}$, both determine central bank demand. These flows are originally in foreign currency and are therefore converted at the appropriate cross rates. The regional real bond yields (interest rates, $r_{j}$ ) emerge from this equality. Their convergence across regions is larger the larger are the elasticities of asset substitution, $\sigma_{j}^{I}$.

The balance of payments condition requires that the sum of net inflows of payments on the current account and net inflows on the capital and financial accounts, measured in a single (home) currency is zero:

$$
X_{i}-M_{i}+\sum_{j \neq i}\left(\left[i_{j i}^{S} S_{j}^{D}+\theta_{j i}^{Q E} S_{j}^{Q E} \Delta M_{j}^{B}\right] \frac{E_{j}}{E_{i}}\right)-\sum_{j \neq i}\left(i_{i j}^{S} S_{i}^{D}+\theta_{i j}^{Q E} S_{i}^{Q E} \Delta M_{i}^{B}\right)=0, \quad \forall i \neq{ }^{\prime \prime} U S^{\prime \prime}
$$

The first terms are values of exports and imports (formulated in the appendix) while the second two terms are financial inflows and outflows. The first parenthesised term represents acquisitions of region $i$ 's home-issued long bonds by foreign savers and by foreign central banks, the latter associated, as above, with the "quantitative easing” component of the current period's expansions of the monetary bases across regions. These net saving and central bank flows are originally in foreign currency and so are converted at the appropriate cross rates. The second parenthesised term represents acquisitions of foreign-issued long bonds by region i's home savers and its own central bank. A balance of payments in the US is implied by 
balance in all the other regions. These equations determine the nominal exchange rates. Since these are defined relative to the US\$, that for the US is always unity $\left(E_{U S}=1\right)$.

The supply side

Six regions are identified: the US, the EU, Japan, China, Australia and the Rest of the World. $^{24}$ Each region supplies a single product that is also differentiated from the products of the other regions and this product is both consumed directly and used as an intermediate input at home and abroad. There are three primary factors with low-skill labour a partially unemployed variable factor while the stocks of physical capital and skill are exogenous and fully employed. Although each region supplies a unique differentiated product, production is assumed to draw on a combination of intermediate inputs comprising the home product and imports of products supplied abroad. This allows the capture of differences between the international effects of a policy change in one large country that are due to the dependence of smaller countries on the supply of inputs on the one hand or final products on the other.

The central production technology is expressed in Cobb-Douglas form. Output and factor inputs are included as relative to initial levels so that shocks to productivity or factor shares do not imply changes in initial output volumes, thus facilitating the subsequent decomposition of technology shocks as between productivity and factor or input bias. In region i gross output volume, $y_{i}$, is a Cobb-Douglas composite of real value added, $v_{i}$, and of intermediates, $q_{i}$.

$$
\frac{y_{i}}{y_{i}^{0}}=\left(\frac{A_{i}^{Y}}{A_{i}^{Y 0}}\right)\left(\frac{v_{i}}{v_{i}^{0}}\right)^{\beta_{i}^{V}}\left(\frac{q_{i}}{q_{i}^{0}}\right)^{\left(1-\beta_{i}^{V}\right)}, \forall i, i \in(\text { regions }),
$$

where $A^{Y}$ is total (factor and input) productivity. Value added, in turn, has Cobb-Douglas dependence on domestic primary factors, raw labour, $L$, skill, $S$ and physical capital, $K$.

$$
\frac{v_{i}}{v_{i}^{0}}=\left(\frac{A_{i}^{V}}{A_{i}^{V 0}}\right)\left(\frac{L_{i}}{L_{i}^{0}}\right)^{\beta_{i}^{L}}\left(\frac{S_{i}}{S_{i}^{0}}\right)^{\beta_{i}^{S}}\left(\frac{K_{i}}{K_{i}^{0}}\right)^{\beta_{i}^{K}}, \sum_{f} \beta_{i}^{f}=1, \forall i, f \in(\text { factors }) .
$$

To allow for inter-regional substitution in intermediate demand across regional sources, domestically employed intermediate inputs, $q$, are a CES composite of products acquired from all regions:

\footnotetext{
${ }^{24}$ The EU is modeled as the full 28 and it is assumed that this collective has a single central bank.
} 


$$
q_{i}=\left(\sum_{j} \alpha_{i j}^{Q} q_{i j}^{-\theta_{i}^{Q}}\right)^{-\frac{1}{\theta_{i}^{Q}}}, \forall i,
$$

where $q_{i j}$ is the quantity of region $j$ 's product that is absorbed by production in region $i$.

The composite prices of value added and intermediate inputs from (7) are related via:

$$
\frac{P_{i}^{V}}{P_{i}^{P}}=\beta_{i}^{V} \frac{y_{i}}{v_{i}}, \frac{P_{i}^{Q}}{P_{i}^{P}}=\left(1-\beta_{i}^{V}\right) \frac{y_{i}}{q_{i}}, \forall i
$$

Here $P_{i}^{P}$ is the producer price level - the factory gate price of region $i$ 's product. The real production wages of unskilled and skilled workers and the capital rental rate depend conventionally on the corresponding marginal products.

The gross volume of output, $y$, is distinguished from real GDP, which is that portion of output that meets final demand, excluding intermediate use, and which equates to real value added, $v$ in (7). The complete set of demands facing country $i$ 's industries, which must sum to equate with (7), takes the form:

$$
y_{i}=\frac{I_{i}+G_{i}}{P_{i}^{P}}+\sum_{j} c_{j i}+\sum_{j} q_{j i}
$$

which is a real version of the standard expenditure identity (on the homogeneous domestic output of region $i$ ) with intermediate demand included. $I$ and $G$ are nominal gross investment and nominal government spending net of transfers, $c_{j i}$ is the volume of final consumption of region $i$ 's product in region $j$, and $q_{j i}$ is the volume of region $i$ 's product that is absorbed as intermediate inputs by production in region $j$. Net trade is embodied in the second term and real GDP omits the final term. Equating this with (7) determines producer price levels, $P^{P}$, in each region. Producer cost minimisation at these prices then determines all the unit factor rewards.

\section{Household disposable income}

Disposable income, for each household, takes the form:

$$
\begin{aligned}
Y_{h i}^{D}= & s_{h i}^{L}\left[\left(1-t_{i}^{L}\right) W_{i} L_{i}+\alpha_{i} W_{i}^{o}\left(F_{i}-L_{i}\right)\right]+s_{h i}^{S}\left(1-t_{i}^{S}\right) W_{i}^{S} S_{i}^{K}, \\
& +s_{h i}^{K}\left(1-t_{i}^{K}\right) K_{i}\left(P_{i}^{P} M P_{i}^{K}-P_{i}^{K} \delta_{i}\right)+T_{h i}^{R}, \quad \forall h
\end{aligned}
$$

where $T_{h}^{R}=t_{h}^{R} N_{h} Y$ is a direct transfer to the household from government revenue, with $t_{h}^{R}$ the transfer rate to household $h$ per unit of group population, $N_{h}$, and per unit of nominal 
GDP. ${ }^{25}$ For each household, $h$, in region $i$, consumption expenditure, $C_{h i}$, is a nominal sum but real consumption behaviour is motivated by current and expected future real, per capita, disposable incomes and the real interest rate. Real consumption, (lower case) $c_{h i}$, depends negatively on the after-tax real return on savings (the home bond yield, $r$ ) and positively on both current and expected future real disposable income per capita for that household:

$$
c_{h i}=\frac{C_{h i}}{P_{i}^{C}}=N_{i}^{h} A_{h i}^{C}\left(\frac{r_{i}}{\tau_{i}^{h}}\right)^{-\varepsilon_{h i}^{C R}}\left(\frac{Y_{h i}^{D}}{N_{i}^{h} P_{i}^{C}}\right)^{\varepsilon_{h i}^{C Y}}\left(\frac{Y_{h i}^{D e}}{N_{i}^{h} P_{i}^{C}\left[1+\pi_{h i}^{C e}\right]}\right)^{\varepsilon_{h i}^{C Y}},
$$

where the tax rate on interest income, $\tau^{h}$, is household specific, set as the tax rate on the households dominant source of direct factor income. The expected inflation rate of the consumer price level is $\pi^{c e}$. The elasticities in this expression vary by household, ensuring different consumption responses.

\section{Consumption driven trade and composite pricing}

To capture the home household's substitution between home and foreign products, real aggregate consumption in region $i$ is a CES composite of region $i$ 's consumption of products from all regions:

$$
c_{i}=\left(\sum_{j} \alpha_{i j}^{C} c_{i j}^{-\theta_{i}^{C}}\right)^{-\frac{1}{\theta_{i}^{C}}}
$$

The home household then chooses its mix of consumed products to minimise consumption expenditure in a way that accounts for home consumption and trade taxes, foreign export taxes, differing foreign product prices and exchange rates:

$$
C_{i}=P_{i}^{C} c_{i}=P_{i}^{P} \tau_{i}^{C} c_{i i}+\sum_{j \neq i} \tau_{i}^{C} \tau_{i}^{M} \tau_{j}^{X} c_{i j} P_{j}^{P} \frac{E_{j}}{E_{i}},
$$

where $\tau_{i}^{C}$ is the power of region $i$ 's consumption tax. Optimum consumption is consistent with an elasticity of substitution between home and foreign products of $1 /\left(1+\theta_{i}^{C}\right)$. Given these consumption volumes, the composite price of all consumption, or the consumer price level, emerges as:

\footnotetext{
${ }^{25}$ The expression (12) is more complex if the labour force participation rates of low skill workers, $\lambda_{L h}$, are unequal across households and, similarly, if participation rates of skilled workers, $\lambda_{S h}$, are unequal across households. The simpler expression is offered here since this is not the case in this analysis. The participation rates within skill groups and across households are kept equal in the experiments conducted, although the rates differ between skill groups and may be differently shocked.
} 


$$
P_{i}^{C}=\tau_{i}^{C}\left[\left(\alpha_{i i}^{C}\right)^{\sigma_{i}^{C}}\left(P_{i}^{P}\right)^{1-\sigma_{i}^{C}}+\tau_{i}^{M} \sum_{j \neq i}\left(\alpha_{i j}^{C}\right)^{\sigma_{i}^{C}}\left\{\frac{P_{j}^{P} E_{j}}{E_{i}}\right\}^{1-\sigma_{i}^{C}}\right]^{\frac{1}{1-\sigma_{i}^{C}}}
$$

The above are critical equations in this model of the global macro-economy. The complete model is documented in the appendix which is available upon request from authors.

\section{Simulating Deflationary Forces}

Here we implement stylised shocks, first to choices of technique that disadvantage low-skill labour, for which our shorthand is automation, then to tax rates on capital income, which decline collectively, and, finally, to migration flows from the "Rest of World" region to Europe, the US and Australia. The automation shocks continue the decline in the low-skill share that is apparent from Figure 8. The model structure we use (equations 7 and 8 in the previous section) allows these shocks to be introduced while holding TFP constant, so that they represent pure factor bias. ${ }^{26}$ The capital taxation shock is a uniform reduction in the power of capital income tax rates by five per cent and the migration shock is a continuation of the recent migration contributions to population growth illustrated in Figure 9. Age distribution effects are ignored so that corresponding shocks are applied to labour forces and the same rates are applied to the low-skill and skilled labour forces. The proportional shocks are largest by far for Australia but significant in Europe given its comparatively static population.

The three sets of shocks are imposed over a decade under the following closure assumptions. First, labour markets are assumed to maintain their current level of clearance, so that there are no changes in regional unemployment rates. Second, there is no change in nominal government spending in each region, nor in government fiscal positions. Adjustments for fiscal balance take place via changes in rates of tax on consumption expenditure. We do this because, as conventional tax bases (incomes to skill and capital) become more inaccessible due to the international mobility of these factors, the rising need to finance transfers must be met from indirect taxation, and consumption expenditure is the elephant in that room. Importantly, however, these simulations offer no new government intervention (system of taxes and transfers) to address the increases in inequality that emerge. The wage rates of low-skill workers fall, as do the incomes of the households that depend on them. Third,

${ }^{26}$ This follows the more detailed national level analysis by Tyers and Zhou (2017). 
scope is allowed for changes in investment flows to cause international redistributions of the global capital stock. The results are then annualized and presented in the form of growth rates. Because our line of reasoning goes primarily from income redistritution to saving, then to real equilibrium interest rates and thence to money demand, we begin with the distributional effects of these shocks.

\subsection{Distributional Effects:}

To see the extent of the redistributions that emerge from the prospective deflationary shocks, we observe the impacts of each on the real purchasing power of disposable income per capita for households depending for their incomes on low-skill labour, skill and capital. The results are shown in Table 1. In all cases the affected regions face redistributions of income toward capital owning households, even where the shocks also benefit working households. Migration shocks neither apply to Japan, nor to China, and so the relative performances of their working and capital-owning households are unaltered. The redistributions are, understandably, largest in the case of biased changes in choice of technique, which we summarise as automation.

The pattern in response to company tax reductions is that first movers gain from capital injections and these offer benefits to working households. Even when, as simulated, the tax reductions spread to all regions, worker households in the US, Europe and Australia appear to be minor net beneficiaries. These benefits, however, are swamped by those accruing to capital owners in all regions. This pattern is sustained when the distributional effects of all three shocks are added together. Even though some low-skill, working household groups across the regions appear to derive small benefits, overall the net gains to these households are negative or insignificant compared to those accruing to capital owners, which, from these deflationary forces alone, enjoy real per capita disposable income growth of between 1.6 (Japan) and 2.5 (Europe) per cent per year. Indeed, the gap between benefits to the capital owning households and the low-skill households expands due to these forces alone at an annual rate of between 2.5 and 3.5 per cent per year.

\subsection{Equilibrium Yield Effects}

The simulated changes in long yields are detailed in Table 2. Two forces are in action. First, the income concentrating effects of the shocks raise global saving rates relative to regional investment, reducing real long yields. Second, UMP is assumed to persist in Europe and Japan and the increases in money demand associated with these shocks, to be detailed below, 
require further central bank asset expansions. This additional bond buying by their central banks raises long bond prices and further reduces their yields. Incomplete global bond market arbitrage sees these effects spread across global financial markets, with the result that the regional long rate changes are similar across regions.

\subsection{Money Demand Effects}

All three shocks require monetary expansions to sustain inflation targets, though magnitudes vary by shock and across regions. As modelled, via expression (3), money demand has three determinants. First, there is transaction financing for the economy's gross product, which includes transacted intermediate inputs. ${ }^{27}$ Second, we include financial transactions demand that rises with financial wealth, and hence increases with growth and inequality, and third, there are portfolio adjustments in response to the declines in long yields, which encourage greater holdings of portfolio money. Under our no-growth equilibrium with zero inflation targets and anchored inflation expectations, the sizes of the simulated changes in money demand are measures of the power of each deflationary force. These changes are indicated in Table 3.

The monetary implications of the automation shocks appear to be stronger in all regions than the other two deflationary shocks. Automation suppresses real wage costs while at the same time boosting the incomes of capital-owning households, whose saving contributes to the long yield declines discussed above that, in turn, reduce the opportunity cost of holding portfolio money. The gains to capital owners see substantial asset portfolio expansion, which contributes more than the other two determinants to rises in money demand. Portfolio rebalancing in response to reduced long yield is the next largest contributor. The traditional perspective that money demand relies on goods transactions demand offers the minor contribution here. Notably, however, this contribution is largest in the case of the migration shocks, in the migrant receiving regions. It is in these regions that migrants boost both real output and the volume of goods transactions. Indeed, in the case of Australia, where immigration is the major contributor to population growth (Figure 9), the growth in money demand due to immigration is largest and the contribution of goods transactions demand is largest across the regions.

\footnotetext{
${ }^{27}$ The redistribution to high-saving capital-owning households suggests the possibility of a decline in consumption volume and a corresponding decline in product transaction demand. This does not occur in the simulations. All products, including intermediates, are transacted, and gross output rises in response to these shocks in all advanced economies. Real consumption also increases overall, though that by low-skill households contracts in regions not receiving immigrants.
} 
Overall, as simulated, the three prospective deflationary forces require annual monetary expansions in the range of 2.2 to 3.2 per cent. This places demands on monetary authorities, which are constrained by the ZLB at the short end and downward pressure on rates at the long end. For the US, this compares with a growth rate of M3 since 2013 of about five per cent per year, which has arisen via rising bank lending and a rise in the money multiplier, without any significant change in the monetary base. ${ }^{28}$ Plans for the Fed to contract its asset portfolio, however, will be contractionary and so meeting demands from the three deflationary forces will depend on further liquidity creation by the private sector. In the case of Australia, the growth of M3 in this period has been at about six per cent per year, with corresponding growth in the monetary base and no increase in its much larger money multiplier. ${ }^{29}$ If the three deflationary forces persist, there is a chance that Australia's continued use of conventional monetary policy may be threatened by the ZLB.

\section{Conclusion}

Using a general equilibrium model of the global economy that incorporates representative behavioural parameters, we analyse the effects of three deflationary forces that act primarily by redistributing income in favour of capital owners, thereby raising the rate of growth of global saving and reducing real yields on long maturity assets. This, in turn, reduces the opportunity cost of portfolio money holding and stimulates the growth of money demand. Under closures that have the advanced regions' central banks target zero inflation, and private inflation expectations anchored at this level, these forces have the effect of requiring increased growth in money supplies in order to avoid deflation. The proximity of short rates to the ZLB and the contribution these forces make to the flatness of the yield curve limit central banks’ capacity to accelerate money supply growth, risking future deflationary episodes.

Because the forces considered are most notably redistributive, their effects on the capacity of central banks to provide macroeconomic stabilisation around growth trends in the advanced economies depend on how governments address the distributional effects. Without further intervention our simulations imply that the gap between benefits to the capital owning and

\footnotetext{
${ }^{28}$ US values for M3 and the monetary base are from FRED, St Louis Fed. They imply a money multiplier that has risen from 2.9 to 3.6 since 2013. This multiplier is low because the monetary base reflects the substantial assets accumulated by the US Fed during its UMP.

${ }^{29}$ Australian values for M3 and the monetary base are from the RBA. They imply a multiplier that has been stable since 2013 at about 19.
} 
low-skill households will expand due to these forces alone at an annual rate of around three per cent per year. With intervention, not only will inequality be constrained but so also will the deflationary impacts of these shocks.

Competing types of intervention include the universal basic income, the popularity of which is rising in Europe, and the earned income tax credit, which originates from the US. While the earned income tax credit appears to offer better outcomes (Tyers and Zhou 2017), mainly because it maintains higher levels of employment and output, both will require more "fiscal space” than is currently available in the advanced economies. This, in turn, will require transitions to more indirect taxation regimes that will, at least temporarily, be inflationary. The race to the bottom under way on capital income taxation will advantage low-skill households in the US and other first moving regions but capital-owning households disproportionately. Eventually, however, it will reduce fiscal space. A redistribution of the taxation burden toward indirect taxes is an essential development on the horizon, particularly in North America and Japan but also in Australia. With fiscal interventions such as an indirect tax financed earned income tax credit system, the effects on long maturity yields and money demand would be smaller. The inescapable conclusion is that the tasks of macro stabilisation on the one hand and maintaining acceptable distribution on the other are now deeply intertwined.

\section{References}

Acemoglu, D., D.H. Autor, D. Dorn, G. Hanson and B. Price (2016), "Import competition and the great US employment sag of the 2000s", Journal of Labor Economics, 34 (S1, 2): S141-S198, January.

Amato, J.D. and S. Gerlach (2002), "Inflation targeting in emerging market and transition economies: Lessons after a decade”, European Economic Review, vol. 46, no. 4-5, pp. 781-790.

Arora, V., R. Tyers and Y. Zhang (2015), "Reconstructing the savings glut: the global implications of Asian excess saving”, International Journal of Economics and Finance, 7(7): 19-42, July.

Auer, R., C. Borio and A. Filado (2017), "The globalisation of inflation: the growing importance of global value chains”, CESifo Working Paper No. 6387, March.

Bagus, P. (2015), In Defense of Deflation, Financial and Monetary Policy Studies 41, Switzerland: Springer, 215pp.

Bank for International Settlements (BIS, 2017), "International banking and financial market developments”, BIS Quarterly Review, September. 
Ball, L. (2014), “The case for a long-run inflation target of four percent”, IMF Working Paper 14/92, June.

Baumol, W. (1952), “The transaction demand for cash: an inventory theoretic approach”, Quarterly Journal of Economics, 66:545-556.

Bentolila, S., J.J. Dolado, J.F. Jimeno (2007), “Does immigration affect the Phillips Curve?” IZA Discussion Paper, No. 3249.

Bewley, T. (1999), Why Wages Don't Fall During a Recession, Cambridge MA: Harvard University Press.

Bhatnagar, S, A. Cormier, K. Hess, P. de Leon-Manlagnit, E. Martin, V. Rai, R. St Cyr and S. Sarker (2017), “Low inflation in advanced economies: facts and drivers”, Bank of Canada Staff Analytical Note, 2017-16.

Blanchflower, D.G., J. Saleheen and C. Shadforth (2007), “The impact of the recent migration from Eastern Europe on the UK economy”, Bank of England Quarterly Bulletin, Vol. 47, No. 1, pp 131-136.

Blitz, R. and M. Mackenzie (2017), "Moments when central banks set pulses racing”, Financial Times, 27 December, p 18.

Bloch, H. (2018), Schumpeter's Price Theory, London: Routledge, 174pp.

Brainard, L. (2017), "Understanding the disconnect between employment and inflation with a low neutral rate”, remarks at The Economic Club of New York, 5 September.

Broadman, H.G. (2017), “Will A Global Corporate Tax Cutting-War Yield The Intended Benefits?” Forbes, 31 December.

Brookings Institution (2018), "Should the Fed stick with the 2 percent inflation target or rethink it?” Conference, 8 January, Washington DC.

Brynjolfsson, E., Rock, D. and Syverson, C. (2017), “Artificial intelligence and the modern productivity paradox: A clash of expectations and statistics”, NBER Working Paper, No. 24001.

Burns, A., M. Kida, J. Lim, S. Mohapatra and M. Stocker (2014) "Unconventional monetary policy normalisation and emerging-market capital flows”, $\underline{V O X}$ : 21 January.

Chodorow-Reich, G. (2015), "Effects of unconventional monetary policy on financial institutions”, NBER Working Paper, No. w20230, Cambridge, MA, June

Christensen, J.H.E. and J.A. Lopez (2016), "Differing views on long-term inflation expectations,” Federal Reserve Bank of San Francisco Economic Letter No. 2016-11, 4 April.

Ciccarelli, M., J.A. Garcia and C. Montes-Galdon (2017), "Unconventional monetary policy and the anchoring of inflation expectations”, ECB Research Paper No. 1995, January.

Cochrane, J. (2015), “Whither inflation?” The Grumpy Economist, 31 August.

Communale, M. and J. Striaukas (2018), "Unconventional monetary policy: interest rates and low inflation: a review of literature and methods”, CAMA Working Paper 29/2017, Australian National University, April.

Demary, M. and M. Hüther (2015), "When low interest rates cause low inflation”, Intereconomics, 50(6): 350-355. 
Dreger, C. and J. Wolters (2015), “Unconventional monetary policy and money demand”, Journal of Macroeconomics, Vol. 46, pp. 40-54.

Duval, R., K. Cheng, K.H. Oh, R. Saraf and D. Seneviratne (2014), "Trade integration and business cycle synchronization: a reappraisal with focus on Asia,” IMF Working Paper, 14/52, Washington DC.

Economist (2017a), "Money mountains: is there any rational justification for tech firms' huge cash piles?” Schumpeter, 3 June, p 58.

Economist (2017c), “Global inflation: gone missing”, Finance and Economics, 4 November, p 71.

Fawley, B.W., C.J. Neely (2013), “Four stories of quantitative easing”, Federal Reserve Bank St. Louis Review, 95(1): 51-88.

Feenstra, R.C., R. Inklaar and M.P. Timmer (2015), "The Next Generation of the Penn World Table,” American Economic Review, 105(10), 3150-3182, at www.ggdc.net/pwt.

Fessenden, H. (2017), “Waiting for inflation: when is inflation too low?” Economic Focus, Q3: 3-6, US Federal Reserve.

Financial Times (2017), “Hard times for humble savers in the years ahead”, Editorial, 27 December, p 8.

Friedman, M. (1968), “The role of monetary policy”, American Economic Review, LVIII (1): $1-17$.

Gagnon, E., K. B.K. Johannsen and D. Lopez-Salido (2016), "Understanding the new normal: the role of demographics", Finance and Economics Discussion Series, Divisions of Research \& Statistics and Monetary Affairs, Federal Reserve Board, Staff Working Paper, 2016-080, Washington, D.C.

Glugliano, A. (2017), “The financial system’s weak link: zombie firms”, Bloomberg, 19 September.

Golley, J., R. Tyers and Y. Zhou (2017), "Fertility and savings contractions in China: longrun global implications”, The World Economy, DOI: 10.1111/twec.12602.

Gomme, P. and B. Ravikumar (2015), "Secular stagnation and returns on capital: returns on government debt bear little resemblance to returns on productive capital”, Economic Synopses, No. 19, Federal Reserve Bank of St Louis, 18 August.

Goodhart, C. and M. Pradhan (2018), Demographics will Reverse Three Multi-Decade Global Trends, Bank for International Settlements Working Paper No. 656, Basel August.

Gozgor, G. and P. Ranjan (2017), "Globalisation, inequality and redistribution: theory and evidence”, The World Economy, 40(12): 2704-2751, December.

Grishchenko, O., S. Mouabbi and J.P. Renne (2016), “The joint dynamics of the US and Euro-area inflation: Expectations and time-varying uncertainty”, Federal Reserve Board and Melbourne Institute Macroeconomic Policy Meeting, October.

Groningen Growth and Development Centre (2013), The Penn World Tables 8.0: TFP at Constant National Prices (2005=1), 2011. Data-Planet ${ }^{\mathrm{TM}}$ Statistical Ready Reference by Conquest Systems, Inc. [Data-file]. Dataset-ID: 071-001-013, http://dx.doi.org/10.6068/DP141761C62519. 
Grossman, G.M. and E. Rossi-Hansberg (2008), “Trading tasks: A simple theory of offshoring”, American Economic Review, 98(5): 1978-1997.

Guardian (2018), “A fall in migration after Brexit could push up inflation, says Carney”, Tuesday $19^{\text {th }}$ September 2017.

Harris, K., A. Kimson and A. Schwedel (2018), Labour 2030: The Collision of Demographics, Automation and Inequality, Bain and Company Report, 7 February, www.bain.com/publications/articles.

Holston, K., T. Laubach and J.C. Williams (2018), "Measuring the natural rate of interest: international trends and determinants”, Journal of International Economics, forthcoming.

Kavuri, A.S. and W.J. McKibbin (2017), “Technology and leisure: macroeconomic implications”, CAMA Working Paper, 43/2017, Australian National University, July.

Keynes, J.M. (1950), A Treatise on Money, Vols I and II, London: Macmillan, volumes first published in 1914 (363pp) and 1930 (409pp). (2007), The General Theory of Employment, Interest and Money, London: Palgrave Macmillan, 472pp, first published in 1936.

Kirby, S. and Riley, R. (2006), "Net migration and the macroeconomy: Inflation and output effect”, National Institute Economic Review, No. 195, pp. 60-62.

Krishnamurthy, A. and A. Vissing-Jorgensen (2012), “The aggregate demand for Treasury debt”, Journal of Political Economy, 120(2): 223-267, April.

Krugman, P. (2014), “Inflation targets reconsidered”, Draft paper for ECB Sintra Conference in May 2014, online available at https://online.ercep.com/media/attachments/inflation-targets-reconsidered-en70089.pdf

Lagarde, C. (2016), “Global ‘economic malpractice”, Financial Times, 29 September 2016, https://www.ft.com/content/7927e142-8587-11e6-8897-2359a58ac7a5.

Laubach, T. and J. Williams (2003), "Measuring the natural rate of interest”, Review of Economics and Statistics, 85(4): 1063-1070.

Lee, R. and A. Mason (2010), "Some macroeconomic aspects of global population aging”, Demography, Springer; Population Association of America (PAA), 47(1): S151-S172, March.

Liesman, S. (2018), “The Fed: worrying about the next recession, considers changes”, $\underline{C N B C}$ International, 3.06pm Wednesday 10 January.

Ma, G., I. Roberts and G. Kelly (2017), “Rebalancing China’s economy: Domestic and international implications”, China and World Economy, Vol. 25, No. 1, pp. 1-31.

Maley, K. (2016), “The global bond bubble looms ever larger”, Australian Financial Review, 11 August.

Malley, J.R., V.A. Muscatelli and U. Woitek (2005), "Real business cycles, sticky wages or sticky prices? The impact of technology shocks on US manufacturing”, European Economic Review, Vol. 49, No. 3, pp. 745-760, April.

Masson, P., M. Savastano and S. Sharma (1997), "The Scope for Inflation Targeting in Developing Countries,” IMF Working Paper No. 97/130. 
Mena, L. and P. Tirelli (2017), “Optimal inflation to reduce inequality”, Review of Economic Dynamics, 24: 79-94.

Nickell, S. (2007), “Immigration: trends and macroeconomic implications”, Bank of International Settlements Working Paper, No. 50.

Nickell, S. and J. Saleheen (2015), "The impact of immigration on occupational wages: evidence from Britain”, Bank of England Staff Working Paper No. 574.

OECD (2017), OECD Income Distribution Database (2017), online available at http://www.oecd.org/social/income-distribution-database.htm

OECD (2008), “Tax effects on foreign direct investment”, OECD Policy Brief, online available at https://www.oecd.org/daf/inv/investment-policy/40152903.pdf

Onaran, O., E. Stockhammer and L. Grafl (2011), "Financialisation, income distribution and aggregate demand in the USA”, Cambridge Journal of Economics, Vol. 35, pp. 637661.

Peneva, E.V. and J.B. Rudd (2017), “The pass-through of labor costs to price inflation”, Journal of Money, Credit and Banking, 49(8), December.

Price, B. (2016), “Bond market is in an 'epic bubble of colossal proportions,' says Boockvar”, $\underline{C N B C}$, 7 July.

Rachel, L. and T. Smith (2015), "Secular drivers of the global real interest rate”, Bank of England Working Paper No. 571, 11 December.

Ragot, X. (2014), “The case for a financial approach to money demand”, Journal of Monetary Econometrics, 62, March, pp. 94-107.

Rognlie, M. (2016), "What lower bound? Monetary policy with negative interest rates”, Brookings Institution, Washington DC.

Rosengren, E.S. (2014), "Implications of low inflation rates for monetary policy”, Washington and Lee University’s H. Parker Willis Lecture in Political Economy.

Rudebusch, G.D. and T. Wu (2008), “A macro-finance model of the term structure, monetary policy and the economy”, Economic Journal, 118(530): 906-926.

Shiller, R. (2017), “The economy is stagnant because people fear for the future”, The Guardian, Business, 23 May.

Summers, L.H. (2014), "Secular stagnation and monetary policy”, Federal Reserve Bank of St. Louis Review, Second Quarter, Vol. 98, No. 2, pp. 93-110. (2016), "The age of secular stagnation: what it is and what to do about it", Foreign Affairs, March-April, pp. 2-9. (2017), “Five reasons why the Fed might be making a mistake”, Washington Post, Analysis: 14 June.

Tabellini, G. (2014), “Inflation Targets Reconsidered: Comments on Paul Krugman”, $\underline{\text { IGIER }}$ - Universita Bocconi Working Paper Series, No. 525.

Taylor, G. and R. Tyers (2017), "Secular stagnation: a survey of determinants and consequences for Australia”, The Economic Record, 93(303): 615-650.

Taylor, J. (1993), Discretion Versus Policy Rules in Practice, Carnegie-Rochester Conference Series on Public Policy, Vol. 39: 195-214. 
Timmer, M.P., E. Dietzenbacher, B. Los, R. Stehrer and G.J. de Vries (2015), “An Illustrated User Guide to the World Input-Output Database: the Case of Global Automotive Production”, Review of International Economics, 23(3): 575-605.

Tobin, J. (1956), “The interest elasticity of transactions demand for cash”, Review of Economics and Statistics, 38: 241-247.

Tobin, J. and D. Hester (1967), Risk aversion and portfolio choice, Cowles Foundation Monograph 19, New York: Wiley.

(1967), Financial Markets and Economic Activity, Cowles Foundation Monograph 21, New York: Wiley.

Tyers, R. (2015a), "Pessimism shocks in a model of global macroeconomic interdependence", International Journal of Economics and Finance, 7(1): 37-59, January.

(2015b), “International effects of China's rise and transition: neoclassical and Keynesian perspectives”, Journal of Asian Economics, 37: 1-19, April.

Tyers, R. (2016), “China and Global Macroeconomic Interdependence”, The World Economy, 39(11): 1674-1702.

Tyers, R., Y. Zhang and T.S. Cheong (2013), “China's saving and global economic performance”, Chapter 6 in Garnaut, R., F. Cai and L. Song (eds,) China: A New Model for Growth and Development, Canberra: ANU E Press and Beijing: Social Sciences Academic Press, Pp 97-124.

Tyers, R. and Y. Zhou (2017), “Automation and inequality with taxes and transfers”, $\underline{\text { CAMA }}$ Working Paper, 70/2017, Australian National University, November.

Watling, C. (2017), Zombie companies stalk a broken monetary system”, Financial Times, 27 December, p 18.

Wicksell, K. (1898), Interest and prices: a study of the causes regulating the value of money, Translation from German, London: Macmillan, 1936.

Williams, J.C. (2015), “The decline in the natural rate of interest”, article based on the presentation for the NABE panel "The Outlook for the U.S. and Global Economy: Headwinds, Tailwinds and Whirlwinds” on January 3, 2015, online available at https://www.frbsf.org/economicresearch/files/Williams_NABE_2015_natural_rate_FRBSF.pdf

Zhou, Y. and R. Tyers (2017), “Automation and income inequality in China”, CAMA Working Paper, 59/2017. 


\section{Figure 1: Annual Inflation Rates}

Consumer price growth

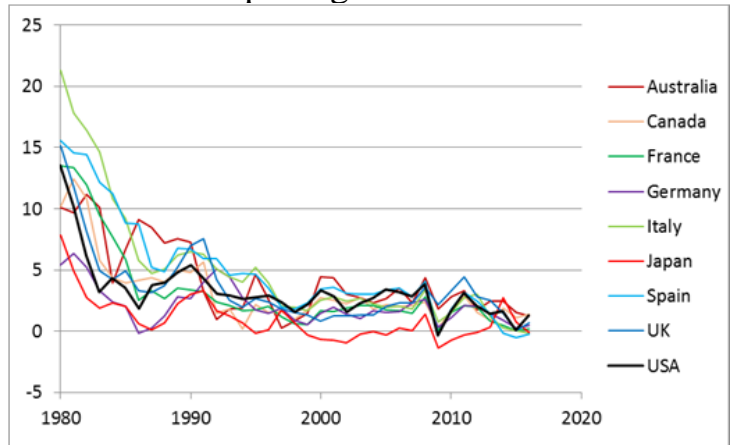

Producer price growth

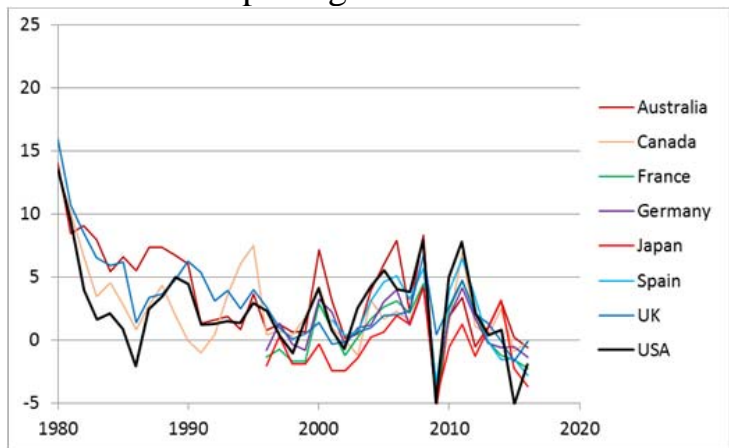

Source: Federal Reserve Bank of St Louis Database (FRED), IMF World Economic Outlook, October 2017.

Figure 2: Government Bond Yields

3 months

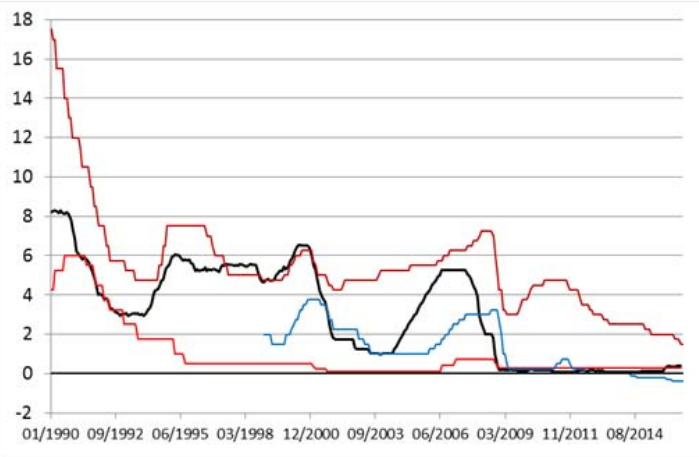

10 years

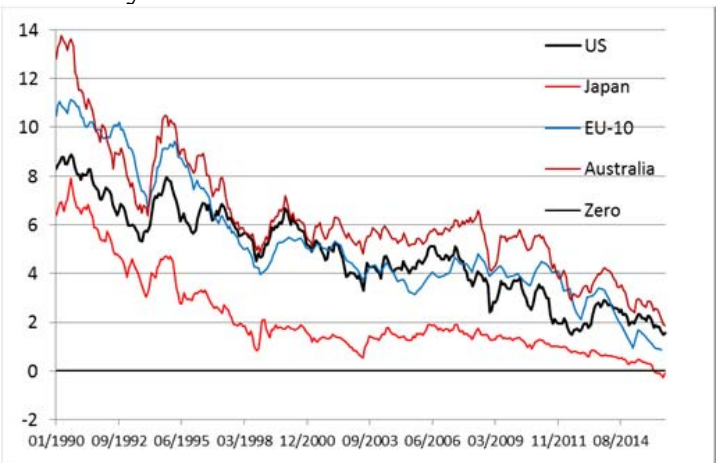

Sources: Sources: US rate from FRB of St Louis (FRED), European rate from European Central Bank (sdw.ecb.europa.eu), Australian rate from the RBA (rba.gov.au/statistics), Japanese rate from ECB (sdw.ecb.europa.eu).

Figure 3: Fiscal Deficits and Sovereign Debt

Deficit to GDP Ratio

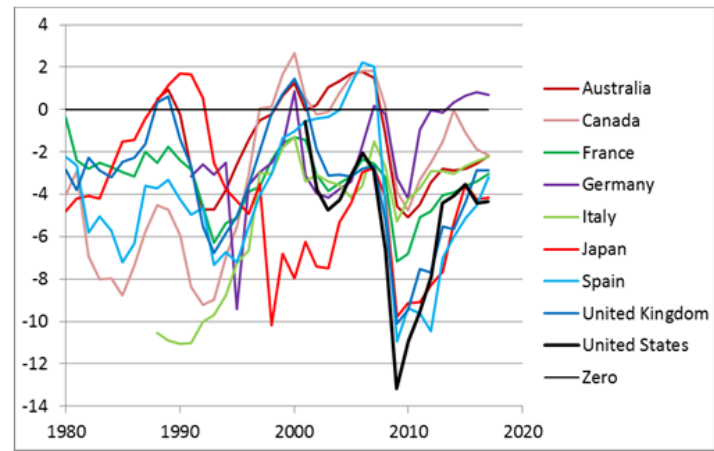

Gross Sovereign Debt to GDP Ratio, \%

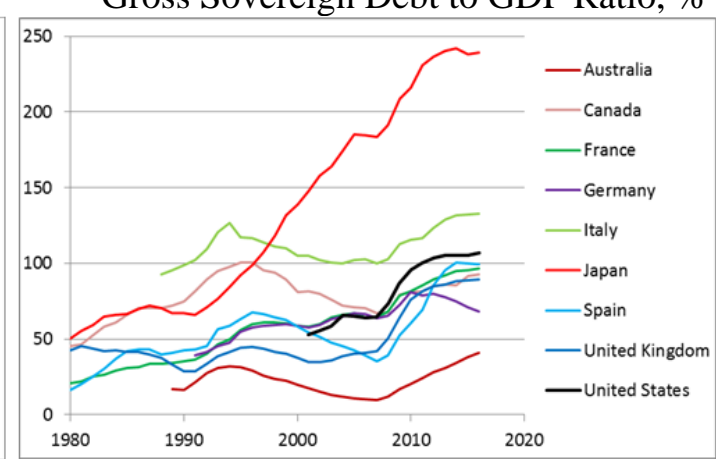

Source: IMF World Economic Outlook, October 2017. 
Figure 4: Real Equilibrium Interest Rate, \% per year

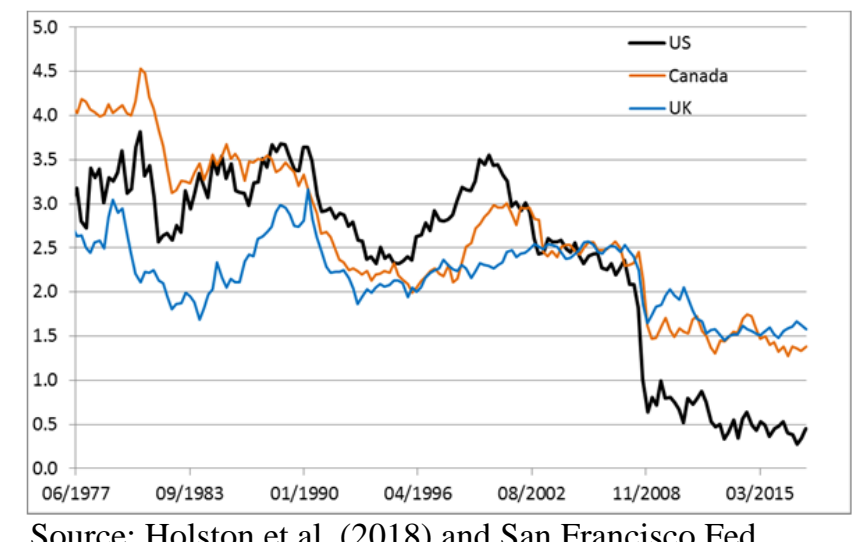

Source: Holston et al. (2018) and San Francisco Fed.

\section{Figure 5. Income Gini Coefficients, Key OECD Countries}

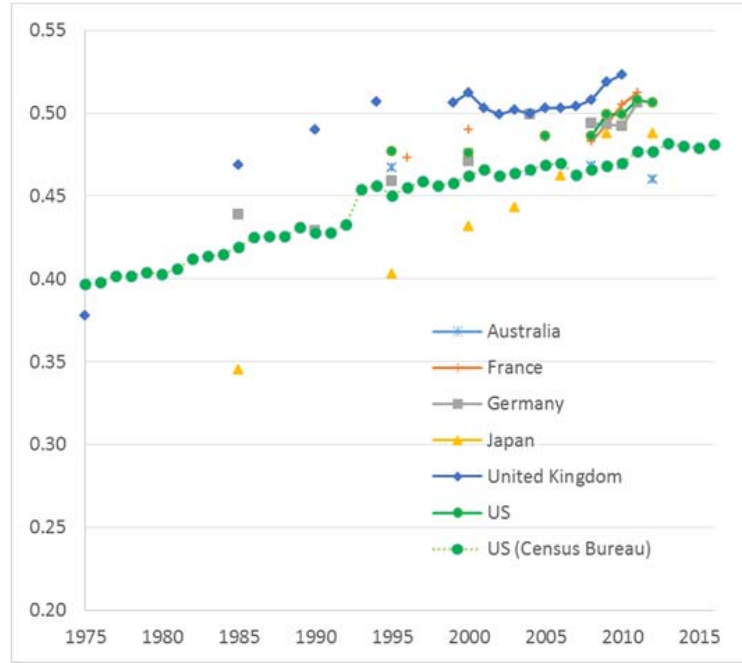

Sources: Unless otherwise stated, OECD Income Distribution Database (OECD 2017). The single continuous series is from the U.S. Census Bureau, Current Population Survey, Annual Social and Economic Supplements.

\section{Figure 6: Real Net National Product per Capita} (1990 US\$)

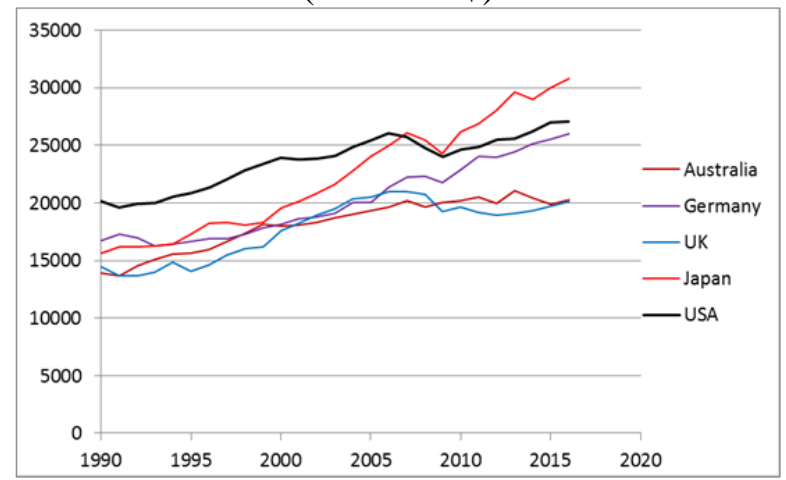

Sources: Deflation is by CPI from IMF: World Economic Outlook. NNP values are from the OECD: National Accounts Statistics. 
Figure 7. Total factor productivity, 1970-2014

(United States, United Kingdom, Australia, OECD overall)

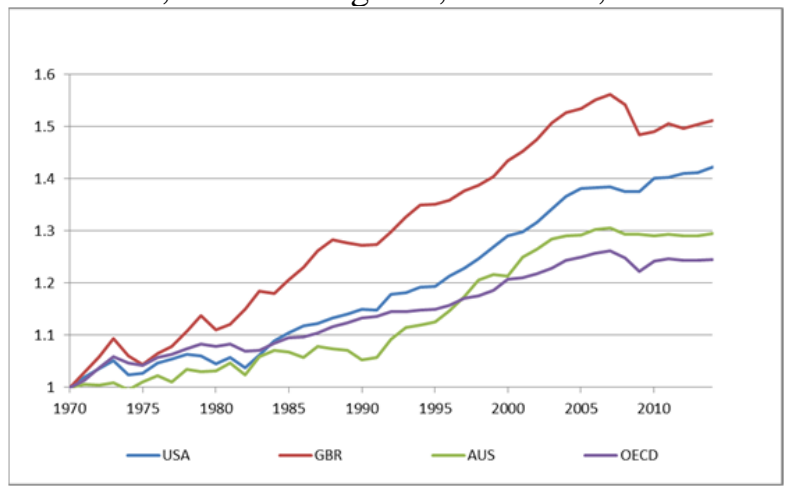

Source: Penn World Tables, international comparisons of production, income and prices, version 9.0. TFP is the portion of output change not explained by the quantities of inputs used in production and is reported at constant national prices (2011=1). We normalize the data to set TFP in 1970 at unity.

\section{Figure 8. Factor Shares of Value Added in the US}

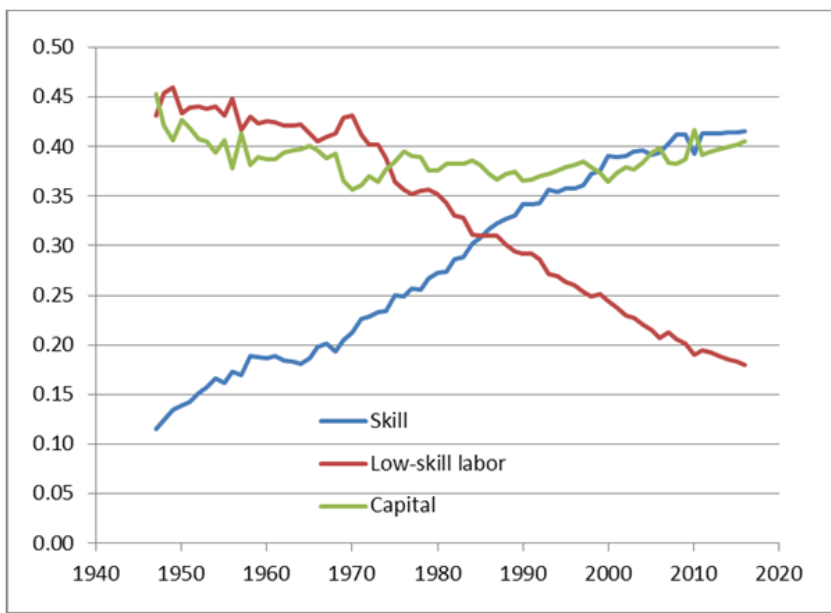

Source: Authors' calculations based on the Penn World Tables (Feenstra et al. 2015) and Socio Economic Accounts, World Input Output Database, 2013 Release (Timmer et al. 2015), along with employment and wage data from FRED. Solid lines indicate historical data. Broken lines indicate extrapolations used in the prospective analysis.

\section{Figure 9: Population Growth in the US, Europe and Australia (\% per year)}

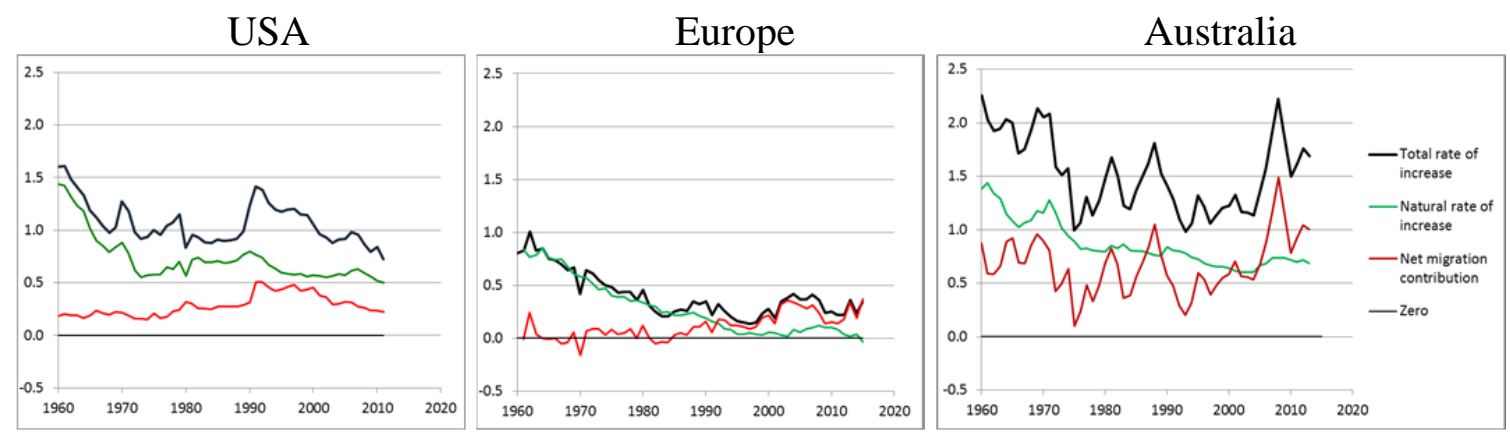

Source: European Commission, Eurostat Population and Population Change Statistics. 
Table 1. Inequality Associated with Prospective Deflationary Forces ${ }^{\mathrm{a}}$

(Annual \% change in real purchasing power at consumer prices of household group disposable income)

\begin{tabular}{|c|c|c|c|c|c|c|}
\hline Deflationary force & Household & USA & $\mathbf{E U}$ & Japan & China & Australia \\
\hline \multirow[t]{4}{*}{ Automation $^{\mathrm{b}}$} & Low skill & -0.92 & -0.43 & -0.95 & -0.54 & -0.82 \\
\hline & Skilled & 0.62 & 1.11 & 0.59 & 1.01 & 0.72 \\
\hline & Capital owning & 1.32 & 1.82 & 1.29 & 1.75 & 1.42 \\
\hline & Low-skill to capital owning gap & 2.24 & 2.25 & 2.24 & 2.28 & 2.24 \\
\hline \multirow{4}{*}{$\begin{array}{l}\text { Company tax rate } \\
\text { reductions }{ }^{c}\end{array}$} & Low skill & 0.03 & 0.09 & -0.02 & -0.13 & 0.03 \\
\hline & Skilled & 0.03 & 0.09 & -0.02 & -0.13 & 0.03 \\
\hline & Capital owning & 0.27 & 0.37 & 0.22 & 0.26 & 0.28 \\
\hline & Low-skill to capital owning gap & 0.23 & 0.28 & 0.25 & 0.39 & 0.26 \\
\hline \multirow[t]{4}{*}{ Migration $^{\mathrm{d}}$} & Low skill & -0.05 & -0.12 & 0.07 & 0.15 & -0.40 \\
\hline & Skilled & -0.05 & -0.12 & 0.07 & 0.15 & -0.40 \\
\hline & Capital owning & 0.25 & 0.28 & 0.06 & 0.15 & 0.59 \\
\hline & Low-skill to capital owning gap & 0.30 & 0.40 & 0.00 & 0.00 & 1.00 \\
\hline \multirow{4}{*}{$\begin{array}{l}\text { Total of the three } \\
\text { forces }\end{array}$} & Low skill & -0.93 & -0.46 & -0.91 & -0.51 & -1.20 \\
\hline & Skilled & 0.60 & 1.08 & 0.63 & 1.03 & 0.34 \\
\hline & Capital owning & 1.84 & 2.47 & 1.58 & 2.16 & 2.30 \\
\hline & Low-skill to capital owning gap & 2.78 & 2.94 & 2.48 & 2.67 & 3.50 \\
\hline
\end{tabular}

a These changes in household real disposable incomes arise from a global model simulation in which migration, company tax rate and automation shocks are imposed. Price level targeting monetary policy regimes are assumed to be maintained in all regions except China and the "rest of the world", which target their US\$ exchange rates, and the results shown are specific to the nominated shocks only. No underlying growth process is included but the capital flows and capital stock adjustments that occur in response are included.

b The automation shock is a fall in the low-skill labour share of total value added in each region by $1.53 \%$ /year, which is the rate at which the share in the US has decline during the past two decades (Tyers and Zhou 2017). This rate is here imposed in all regions without any associated changes in TFP.

c The company tax shock is a one-off, uniform reduction in the power of the capital income tax rate, in all regions, by $5.0 \%$, implemented over 10 years. Lost government revenue is assumed to be made up via increases in consumption tax rates. Results for a US only shock are more modest, though the US deflationary force is stronger due to exchange rate appreciation. These results are available on request.

$\mathrm{d}$ The migration shock raises the low-skill labour force of the US by $0.3 \%$ /year, that of the EU by $0.4 \%$ /year and that of Australia by $1.0 \%$ /year with this labour being deducted from the labour force of the "rest of the world". The same proportional changes are applied to their skilled work forces, though these increments are not deducted from the "rest of the world" under the assumption that its brain drain stimulates training into the lost positions. Note that the changes listed indicate identical effects on the low-skilled and the skilled. This is because the proportional changes in supply are the same for these two categories. 
Table 2. Prospective Deflationary Forces: Simulated Real Long Bond Yield Changes ${ }^{\text {a }}$

(Annual \% change)

\begin{tabular}{|c|c|c|c|c|c|c|}
\hline Deflationary force & USA & $\mathbf{E U}$ & Japan & China & Australia & Rest of World \\
\hline Automation $^{\mathrm{b}}$ & -0.97 & -0.97 & -1.09 & -0.99 & -0.95 & -1.07 \\
\hline Capital tax rate reduction ${ }^{c}$ & -0.41 & -0.39 & -0.42 & -0.48 & -0.37 & -0.68 \\
\hline Migration $^{\mathrm{d}}$ & -0.38 & -0.42 & -0.35 & -0.32 & -0.50 & -0.34 \\
\hline Combined shocks & -1.76 & -1.78 & -1.86 & -1.79 & -1.82 & -2.09 \\
\hline
\end{tabular}

a These are proportional changes in long bond yields (not \% point or basis point changes) arising from a global model simulation in which migration, company tax rate and automation shocks are imposed. Price level targeting monetary policy regimes with anchored expectations are assumed to be maintained in all regions except China and the "rest of the world", which target their US\$ exchange rates, and the results shown are specific to the nominated shocks only. No underlying growth process is included but the capital flows and capital stock adjustments that occur in response are included.

$\mathrm{b}$ The automation shock is a fall in the low-skill labour share of total value added in each region by $1.53 \%$ /year, which is the rate at which the share in the US has declined during the past two decades (Tyers and Zhou 2017). This rate is here imposed in all regions without any associated changes in TFP.

c The company tax shock is a one-off, uniform reduction in the power of the capital income tax rate, in all regions, by $5.0 \%$, implemented over 10 years. Lost government revenue is assumed to be made up via increases in consumption tax rates. Results for a US only shock are more modest, though the US deflationary force is stronger due to exchange rate appreciation. These results are available on request.

$\mathrm{d}$ The migration shock raises the low-skill labour force of the US by $0.3 \%$ /year, that of the EU by $0.4 \%$ /year and that of Australia by $1.0 \%$ /year with this labour being deducted from the labour force of the "rest of the world". The same proportional changes are applied to their skilled work forces, though these increments are not deducted from the "rest of the world" under the assumption that its brain drain stimulates training into the lost positions. 
Table 3. Prospective Deflationary Forces: Simulated Changes in Money Demand by Source ${ }^{\mathrm{a}}$

(Annual \% change)

\begin{tabular}{|c|c|c|c|c|c|c|}
\hline Deflationary force & Observed variable & USA & EU & Japan & China & Australia \\
\hline Automation & $\begin{array}{l}\text { Money growth rate, } \% / y r \\
\% \text { due to goods \& services transactions } \\
\% \text { due to portfolio expansion } \\
\% \text { due to portfolio rebalancing }\end{array}$ & $\begin{array}{l}1.8 \\
15 \\
54 \\
31\end{array}$ & $\begin{array}{r}2.1 \\
14 \\
58 \\
28\end{array}$ & $\begin{array}{l}1.7 \\
13 \\
58 \\
29\end{array}$ & $\begin{array}{l}2.0 \\
23 \\
53 \\
25\end{array}$ & $\begin{array}{l}\mathbf{1 . 9} \\
15 \\
55 \\
31\end{array}$ \\
\hline $\begin{array}{l}\text { Company tax rate } \\
\text { reductions }{ }^{c}\end{array}$ & $\begin{array}{l}\text { Money growth rate, } \% / y r \\
\% \text { due to goods \& services transactions } \\
\% \text { due to portfolio expansion } \\
\% \text { due to portfolio rebalancing }\end{array}$ & $\begin{array}{l}\mathbf{0 . 2} \\
10 \\
42 \\
48\end{array}$ & $\begin{array}{l}0.2 \\
12 \\
46 \\
43\end{array}$ & $\begin{array}{c}\mathbf{0 . 1} \\
7 \\
41 \\
52\end{array}$ & $\begin{array}{l}\mathbf{0 . 4} \\
20 \\
47 \\
33\end{array}$ & $\begin{array}{c}\mathbf{0 . 2} \\
9 \\
42 \\
49\end{array}$ \\
\hline Immigration $^{\mathrm{d}}$ & $\begin{array}{l}\text { Money growth rate, } \% / y r \\
\% \text { due to goods \& services transactions } \\
\% \text { due to portfolio expansion } \\
\% \text { due to portfolio rebalancing }\end{array}$ & $\begin{array}{l}\mathbf{0 . 6} \\
25 \\
42 \\
34\end{array}$ & $\begin{array}{l}\mathbf{0 . 6} \\
26 \\
44 \\
30\end{array}$ & $\begin{array}{c}\mathbf{0 . 4} \\
5 \\
44 \\
51\end{array}$ & $\begin{array}{c}\mathbf{0 . 6} \\
9 \\
39 \\
51\end{array}$ & $\begin{array}{l}1.1 \\
39 \\
42 \\
19\end{array}$ \\
\hline $\begin{array}{l}\text { Total of the three } \\
\text { forces }\end{array}$ & $\begin{array}{l}\text { Money growth rate, } \% / y r \\
\% \text { due to goods \& services transactions } \\
\% \text { due to portfolio expansion } \\
\% \text { due to portfolio rebalancing }\end{array}$ & $\begin{array}{l}2.7 \\
22 \\
44 \\
33\end{array}$ & $\begin{array}{l}3.0 \\
23 \\
47 \\
30\end{array}$ & $\begin{array}{c}2.2 \\
7 \\
48 \\
45\end{array}$ & $\begin{array}{r}3.1 \\
13 \\
43 \\
45\end{array}$ & $\begin{array}{l}3.2 \\
35 \\
44 \\
21\end{array}$ \\
\hline
\end{tabular}

a These changes in monetary bases arise from a global model simulation in which migration, company tax rate and automation shocks are imposed. Price level targeting monetary policy regimes with anchored inflation expectations are assumed to be maintained in all regions except China and the "rest of the world", which target their US\$ exchange rates, and the results shown are specific to the nominated shocks only. Positive growth in monetary bases indicates the expansions required in order to sustain the targets, showing the strength of the associated deflationary forces. No underlying growth process is included but the capital flows and capital stock adjustments that occur in response are included.

b The automation shock is a fall in the low-skill labour share of total value added in each region by $1.53 \%$ /year, which is the rate at which the share in the US has declined during the past two decades (Tyers and Zhou 2017). This rate is here imposed in all regions without any associated changes in TFP.

c The company tax shock is a one-off, uniform reduction in the power of the capital income tax rate, in all regions, by $5.0 \%$, implemented over 10 years. Lost government revenue is assumed to be made up via increases in consumption tax rates. Results for a US only shock are more modest, though the US deflationary force is stronger due to exchange rate appreciation. These results are available on request.

$\mathrm{d}$ The migration shock raises the low-skill labour force of the US by $0.3 \%$ /year, that of the EU by $0.4 \%$ /year and that of Australia by $1.0 \%$ /year with this labour being deducted from the labour force of the "rest of the world". The same proportional changes are applied to their skilled work forces, though these increments are not deducted from the "rest of the world" under the assumption that its brain drain stimulates training into the lost positions. 


\title{
Appendix to
}

\section{Deflation Forces and Inequality*}

\author{
Rod TYERS \\ Business School \\ University of Western Australia, \\ Research School of Economics, \\ Centre for Applied Macroeconomic Analysis (CAMA) \\ Australian National University \\ Yixiao ZHOU \\ School of Economics and Finance \\ Curtin Business School \\ Curtin University
}

First Draft March 2018

Key words:

Inflation, deflation, productivity, automation, income distribution, tax, transfers, general equilibrium analysis

JEL Codes:

D33, E52, J11, O33

Author best contact details:

Rod Tyers

Winthrop Professor of Economics

UWA Business School

Crawley, WA 6009

Australia

rod.tyers@uwa.edu.au

** Thanks are due to Grace Taylor at the Reserve Bank of Australia for assistance with data. The model used in the paper is solved using the Gempack software. 


\section{A1 Modelling Global Macro Interdependence}

The financial sector and monetary policy are central to this model of the global economy. The demand for money as a financial asset is driven by a "cash in advance" constraint applying across the whole of GDP and home money is held in a portfolio with regionally differentiated long maturity bonds, which are claims over physical capital and government debt across the regions. Since portfolios are dominated by long maturity assets, the opportunity cost of holding money is the long bond yield, which is modelled as emerging from equilibrium in a thus weakly segmented global market for loanable funds. Central banks derive monetary expansions in regionally specific proportions from conventional monetary policy and from UMP, with reliance on the market segmentation theory of the yield curve (Johnson et al. 2010) to ensure that conventional monetary policy has no direct impact on the market for long term bonds. Short rates are therefore not modelled explicitly, rather the monetary base in each region is determined as endogenous to the target of monetary policy and an exogenous parameter determines the share of any change in the monetary base that takes the form of long asset balance sheet expansion. UMP expansions raise home long maturity asset prices and lower long yields, causing imperfect spill-overs across regions due to global arbitrage that is only partially constrained by asset differentiation.

Amongst the six regions identified, the US, the EU, Japan, China, Australia and the Rest of the World, the EU is modeled as the full 28 and it is assumed that this collective has a single central bank. In each region there are three households, each with factor-specific income (from low skill labour, skill and physical capital) and each with different reduced form consumption behaviour that depends on the real interest rate and current and expected future real disposable income.

\section{A1.1 Financial Markets and External Balance}

A multi-region general equilibrium structure is used that centres on the global financial capital market. It is assumed that the financial products of each region are differentiated and that portfolio managers assign new net saving across regions so as to maximise expected portfolio returns given this differentiation. Although there is a tendency for financial flows to move the global economy toward uncovered interest parity, in the length of run considered asset differentiation leaves this process incomplete. At the same time, expected rates of 
return depart from regional bond yields, the latter reflecting short run equilibria in regional financial markets, as between savers, indebted governments and investors.

\section{Investment}

Each region's financial market is represented as the market for domestic long maturity assets. These behave like equity, in the sense that income from them is assumed to be taxed after depreciation, even though they include government debt issued to a level that depends on fiscal policy as well as both debt and equity issued by domestic investors. Purchasers of these assets are assumed to respond to changes in an expected rate of return on installed domestic capital, $r^{c e}$, which is net of depreciation and capital tax and adjusted for sovereign risk. This rate of return has a number of components. First, since only the after-depreciation component of capital income is taxed, nominal capital income after tax for region $i$ is:

(A1) $Y_{i}^{K N}=\left(1-t_{i}^{K}\right) K_{i}\left(P_{i}^{P} M P_{i}^{K}-P_{i}^{K} \delta_{i}\right)$,

where $P^{P}$ is the producer price of the regional product ${ }^{30}$ and $P^{K}$ is the price of capital goods. ${ }^{31}$ The ad-valorem tax rate, $t^{K}$, is here defined as the rate applied to income from financial assets, including both debt and equity, and $\delta$ is the depreciation rate of physical capital. The marginal physical product of capital, $M P^{K}$, is derived from the production technology, specified later. It is inversely proportional to the stock of utilized regional capital, $K$. The regional real rate of return net of both tax and depreciation is then: ${ }^{32}$

$$
r_{i}^{C}=\frac{Y_{i}^{K N}}{P_{i}^{K} K_{i}}-\delta_{i}=\left(1-t_{i}^{K}\right)\left(\frac{P_{i}^{P} M P_{i}^{K}}{P_{i}^{K}}-\delta_{i}\right)-\delta_{i}
$$

To obtain the expected future value of this rate, it first adjusted by a sovereign risk factor and then embedded in an uncovered interest parity condition, here operating in real terms:

$$
r_{i}^{c e}=r_{i}^{c}\left(\frac{\varphi_{i}^{0}}{\varphi_{i}}\right)+\hat{e}_{i}^{e}
$$

\footnotetext{
${ }^{30}$ The producer price level is the factory door price of the regional good, which differs in this model from the GDP price level, $P^{Y}$, due to indirect taxation and from the consumer price, $P^{C}$, which includes imported products. This emerges from (A23), below.

${ }^{31}$ In this single product model the product and capital goods prices are separated by a single parameter: $P^{K}=\gamma P^{P}$. This allows shocks to represent the relative cheapening of capital goods over time as their information technology content rises.

${ }^{32}$ This is a real rate of return because it depends on the real volumes, $M P^{K}$ and $K$, adjusted only by the ratio of $P^{P}$ and $P^{K}$. It is therefore impervious to common inflation.
} 
where $\hat{e}^{e}$ is the exogenous, expected proportional change in the real exchange rate and the interest premium factor, $\varphi$, permits consideration of the effects of changes in the fiscal balance on sovereign risk. A deteriorating fiscal balance causes investment to be less attractive. For this reason, a further adjustment is made using an interest premium factor, $\varphi_{i}$, that is defined relative to the US ( $\left.\varphi_{U S}=1\right)$. This permits consideration of the effects of changes in sovereign risk in association with the fiscal balance. Increments to regional sovereign risk, relative to the US, cause investments in regions with increasing fiscal deficits to be less attractive.

$$
\varphi_{i}=\varphi_{i}^{0}\left[\left(\frac{G_{i}}{T_{i}} / \frac{G_{U S}}{T_{U S}}\right)\right]^{\phi_{i}}, \quad \forall i \neq{ }^{\prime \prime} U S^{\prime \prime},
$$

where $\phi$ is a positive elasticity indicating sensitivity to sovereign risk, $G$ is government expenditure net of transfers, $T$ is gross government revenue also net of transfers, and the zero superscripts indicate initial values.

The domestic demand for investment financing then depends on the ratio of the expected real rate of return on installed capital, $r^{c e}$, which is defined as after capital income tax, and the after tax real long bond yield that clears the domestic financial market, $r$. Since the numerator indicates the market value of domestic assets and the denominator the cost of financing their replacement, this is in the tradition of Tobin's Q. Accordingly, since firms do not incur tax when issuing stock or bonds, no taxation is applied in the denominator.

$$
\frac{I_{i}^{D} / P_{i}^{K}}{I_{i}^{0} / P_{i}^{K 0}}=\left[\left(\frac{r_{i}^{c e}}{r_{i}}\right) /\left(\frac{r_{i}^{c e 0}}{r_{i}^{0}}\right)\right]^{\varepsilon_{i}^{I}}
$$

where $\varepsilon^{I}$ is a positive elasticity and the zero superscripts indicate initial values. Since investment demand, $I^{D}$, is defined as nominal, it is adjusted by the capital goods price. The yield ratio deviates from unity not only because income from new investments is taxed after depreciation, but also due to the regional differentiation of assets. In part, this differentiation reflects the fact that, at short to medium lengths of run, the economy is not in a financial steady state.

This investment demand is then matched in each region by a supply of saving that incorporates contributions from all regional households. Here the modelling incorporates explicit portfolios of assets from all regions. Data on regional saving and investment is first 
combined with that on international financial flows to construct an initial matrix to allocate total domestic saving in each region to investment across all the regions. From this is derived a corresponding matrix of initial shares of region $i$ 's net (private and government) saving that are allocated to the local savings supply that finances investment in region $j, i_{i j}^{S 0}$. When the model is shocked, the new shares are calculated so as to favour investment in regions, $j$, whose real yields are boosted by the shock. Since these are portfolio investments, the real rate of return available in each region is assumed to be the domestic market clearing yield, $r$. Region $i$ 's portfolio manager allocates the proportion $i_{i j}^{S}$ of its annual (private plus government) saving to new investments in regions $\mathrm{j}$, such that $\sum_{j} i_{i j}^{s}=1 .^{33}$ Because the newly issued equity is differentiated across regions based on un-modelled and unobserved regionspecific properties, their services are combined via a constant elasticity of substitution (CES) function specific to each regional portfolio manager. Thus, region i's household portfolio management problem is to choose the shares, $i_{i j}^{S}$, of its private saving net of any government deficit, $S_{i}^{D}=S_{i}^{P}+T^{D}+T^{I}-G$, which are to be allocated to the assets of region $\mathrm{j}$ so as to maximise a CES composite representing the value of the services yielded by these assets:

$$
\max _{i_{i j}^{S}} U_{i}^{F}=S_{i}^{D}\left[\sum_{j} \alpha_{i j}\left(i_{i j}^{S}\right)^{-\rho_{i}}\right]^{-\frac{1}{\rho_{i}}} \text { such that } \sum_{j} i_{i j}^{S}=1 \text {. }
$$

Here $\alpha_{i j}$ is a parameter that indicates the benefit to flow from region $i$ 's investment in region $j$. The CES parameter, $\rho_{i}$, reflects the preparedness of region $i$ 's household to substitute between the assets it holds. To induce rebalancing in response to changes in rates of return the $\alpha_{i j}$ are made dependent on ratios of after-tax yields in destination regions, $j$, and the home region, $i$, via: ${ }^{34}$

$$
\alpha_{i j}=\beta_{i j}\left[\frac{r_{j}\left(1-t_{j}^{K}\right)}{r_{i}\left(1-t_{i}^{K}\right)}\right]^{\lambda_{i}} \quad \forall i, j, \quad \lambda_{i}>0 \quad \forall i
$$

\footnotetext{
${ }^{33}$ The manager does not re-optimise over total holdings every year. This is because the model is deterministic and risk is incorporated only via exogenous premia. The motivations for continuous short run rebalancing, other than the arrival of new saving, are therefore not represented.

${ }^{34}$ Note that region $i$ 's market bond yield, $r_{i}$, is determined concurrently and indicates the replacement cost of capital in region $i$ and therefore the opportunity cost for region $i$ 's household of investment in region $j$.
} 
Here, $t_{i}^{K}$ is the rate of capital income tax rate in region $i$. This relationship indicates the responsiveness of portfolio preferences to yields, via the (return chasing) elasticity $\lambda_{i}$. The allocation problem, thus augmented, is:

$$
\max _{i_{i j}^{S}} U_{i}^{F}=S_{i}^{D}\left[\sum_{j} \beta_{i j}\left[\frac{r_{j}\left(1-t_{j}^{K}\right)}{r_{i}\left(1-t_{i}^{K}\right)}\right]^{\lambda_{i}}\left(i_{i j}^{S}\right)^{-\rho_{i}}\right]^{-\frac{1}{\rho_{i}}} \text { such that } \sum_{j} i_{i j}^{S}=1 .
$$

Solving for the first order conditions we have, for region i's investments in regions $j$ and $k$ :

$$
\frac{i_{i j}^{S}}{i_{i k}^{S}}=\left(\frac{\beta_{i j}}{\beta_{i k}}\right)^{\frac{1}{1+\rho_{i}}}\left[\frac{r_{j}\left(1-t_{j}^{K}\right)}{r_{k}\left(1-t_{k}^{K}\right)}\right]^{\frac{\lambda_{i}}{1+\rho_{i}}}
$$

This reveals that region i's elasticity of substitution between the bonds of different regions is $\sigma_{i}^{I}=\lambda_{i} /\left(1+\rho_{i}\right)>0$, which has two elements. The return-chasing behaviour of region $i$ 's household $\left(\lambda_{i}\right)$ and the imperfect substitutability of regional bonds, and therefore the sluggishness of portfolio rebalancing $\left(\rho_{i}\right)$. For the purposes of this analysis the values of $\sigma_{i}^{I}$ are seen as indicating the extent of each region's integration with global financial markets. The optimal share of the net domestic saving of region $i$ that is allocated to assets in region $j$ then follows from (A9) and the normalisation condition, that $\sum_{k} i_{i k}^{S}=1$. Start by setting:

$$
\eta_{i j k}=\frac{i_{i k}^{S}}{i_{i j}^{S}}=\left(\frac{\beta_{i k}}{\beta_{i j}}\right)^{\frac{1}{1+\rho_{i}}}\left[\frac{r_{k}\left(1-t_{k}^{K}\right)}{r_{j}\left(1-t_{j}^{K}\right)}\right]^{\frac{\lambda_{i}}{1+\rho_{i}}} \text {, so } i_{i k}^{S}=i_{i j}^{S} \delta_{i j k}
$$

Then, substituting in the normalisation condition, $\sum_{k} i_{i k}^{S}=1=i_{i j}^{S} \sum_{k} \eta_{i j k}$, which yields

(A11) $i_{i j}^{S}=$

$$
i_{i j}^{S}=\frac{1}{\sum_{k}\left(\frac{\beta_{i k}}{\beta_{i j}}\right)^{\frac{\sigma_{i}^{I}}{\lambda_{i}}}\left[\frac{r_{j}\left(1-t_{j}^{K}\right)}{r_{i}\left(1-t_{i}^{K}\right)}\right]^{\sigma_{i}^{l}}} .
$$

The calibration of the key matrix $\left[\beta_{i j}\right]$ is explained in the appendix. 


\section{The markets for regional money}

Within each region the demand for money is driven by a "cash in advance" constraint. For any one household, home money is held in a portfolio with mainly long maturity assets, which are claims over physical capital, combined with home and foreign long maturity government debt. The cash-in-advance constraint is assumed to generate transactions demand for home money across all components of gross (including intermediate) output. Transactions demand is then augmented by the real purchasing power of financial wealth, to account for the observed dominance of financial transactions over money demand. ${ }^{35}$ The opportunity cost of holding home money is set at the nominal after-tax yield on home long term bonds. ${ }^{36}$ Real money balances are measured in terms of purchasing power over home products at the GDP price, $P^{Y}$.

$$
m_{i}^{D}=a_{i}^{M D}\left(y_{i}\right)^{\varepsilon_{i}^{M Y}}\left(w_{i}^{F}\right)^{\varepsilon_{i}^{M W}}\left(\frac{r_{i}\left(1+\pi_{i}^{e}\right)}{\tau_{i}^{K}}\right)^{-\varepsilon_{i}^{M R}}=\frac{M_{i}^{S}}{P_{i}^{Y}}=\frac{\mu_{i} M_{i}^{B}}{P_{i}^{Y}}
$$

For region $i, y_{i}$ is real, regional gross output, as distinct from real GDP since intermediates are transacted as well as goods and services entering final demand. Real financial wealth is $w_{i}^{F}$, $\tau_{i}^{K}$ is the power of the capital income tax rate in region $i$ and $\pi_{i}^{e}$ is the expected inflation rate of the consumer price level, $P^{C}$, defined as a CES aggregate of home and imported consumer prices. Real financial wealth or assets, $w^{F}$, is represented as the present value of an infinite stream of real dividends that are equal to after-tax returns on the capital stock, at the expected real rate of return on installed capital, $r^{c e}$, discounted at the current real financing rate, $r$. A price adjustment is also made for relative inflation or deflation of capital goods prices, which raise or lower the purchasing power of financial wealth over home products.

$$
W_{i}^{F}=\frac{r_{i}^{c e}\left(1-t_{i}^{K}\right)\left(P_{i}^{K} / P_{i}^{Y}\right) K}{r_{i}}
$$

The last three decades have exhibited advanced region asset price inflation that has exceeded

\footnotetext{
35 The inclusion of financial wealth in the money demand equation follows Ragot (2014) and Mena and Tirelli (2017), who incorporate Baumol (1952) - Tobin (1956) behaviour.

${ }^{36}$ Thus, it is assumed here that the opportunity cost of holding money is measured by the long bond yield, which is the dominant determinant of non-money portfolio yields. Short rates, at least as they have a role in conventional monetary policy, are here embedded in the determination of the monetary base. While housing investment can be sensitive to short rates in economies where most mortgage contracts have variable rates, the assumption that investment financing depends on the long maturity market is a simplifying abstraction in this global analysis.
} 
that in goods, for the US by at least six percentage points per year on average, ${ }^{37}$ suggesting a rising path of this ratio. This comparative growth in financial wealth is due to the many determinants of wealth inequality, including the forces discussed in this paper.

On the supply side of the money market, the proportion of expansions that occur via the purchase of long maturity assets (UMP) is parameterised. Conventional expansions directly affect the money supply while UMP expansions affect both it and the long end of the yield curve. UMP expansions raise home long maturity asset prices and lower long yields, causing imperfect spill-overs due to global arbitrage that is only partially constrained by asset differentiation. $^{38}$

Regional financial market clearance requires that the home financial market in each region clears separately and this implies global financial market clearance. For region $i$, the nominal value of domestic investment, $I_{i}^{D}$, from (5), represents the sum total of all domestic long bond issues. This is then equated with demand for those bonds from home and foreign (net private and government) savings, along with demands for home long bonds that arise from the "quantitative easing" components of monetary expansions by both home and foreign central banks.

\section{Global financial balance}

Financial balance then requires that total investment spending in region $i$, in $i$ 's local currency, is equated with the total supply of financing directed from all represented regions:

(A14) $I_{i}^{D}=\sum_{j}\left(\left[i_{j i}^{S} S_{j}^{D}+\theta_{j i}^{Q E} s_{j}^{Q E} \Delta M_{j}^{B}\right] \frac{E_{j}}{E_{i}}\right), \quad \forall i$

where $E_{i}$ is the nominal exchange rate of region $i$ relative to the US\$, which is the numeraire in the model $\left(E_{U S}=1\right)$. The "quantitative easing" component of the current period's expansion of the monetary base by region $j$ 's central bank, $s_{j}^{O E}$, and the share of this expansion that takes the form of acquisitions of region $i$ 's long bonds, $\theta_{j i}^{Q E}$, both determine central bank demand. These flows are originally in foreign currency and are therefore

\footnotetext{
${ }^{37}$ This is readily concluded from a comparison of the path of a broad index of stock prices, such as the Wilshire Capital Price Index, and the US CPI, since 1990.

${ }^{38}$ By contrast, conventional monetary policy involves trade in short term instruments which has no direct impact on the market for long term bonds. Short rates are therefore not modelled explicitly, rather the monetary base in each region is determined as endogenous to the target of monetary policy and an exogenous parameter determines the share of any change in the monetary base that takes the form of long asset balance sheet expansion.
} 
converted at the appropriate cross rates. The regional real bond yields (interest rates, $r_{j}$ ) emerge from this equality. Their convergence across regions is larger the larger are the elasticities of asset substitution, $\sigma_{j}^{I}$.

The balance of payments condition requires that the sum of net inflows of payments on the current account and net inflows on the capital and financial accounts, measured in a single (home) currency is zero:

$$
X_{i}-M_{i}+\sum_{j \neq i}\left(\left[i_{j i}^{S} S_{j}^{D}+\theta_{j i}^{Q E} s_{j}^{Q E} \Delta M_{j}^{B}\right] \frac{E_{j}}{E_{i}}\right)-\sum_{j \neq i}\left(i_{i j}^{S} S_{i}^{D}+\theta_{i j}^{Q E} S_{i}^{Q E} \Delta M_{i}^{B}\right)=0, \quad \forall i \neq " U S^{\prime \prime}
$$

The first terms are values of exports and imports (formulated in the appendix) while the second two terms are financial inflows and outflows. The first parenthesised term represents acquisitions of region $i$ 's home-issued long bonds by foreign savers and by foreign central banks, the latter associated, as above, with the "quantitative easing” component of the current period's expansions of the monetary bases across regions. These net saving and central bank flows are originally in foreign currency and so are converted at the appropriate cross rates. The second parenthesised term represents acquisitions of foreign-issued long bonds by region $i$ 's home savers and its own central bank. A balance of payments in the US is implied by balance in all the other regions. These equations determine the nominal exchange rates. Since these are defined relative to the US\$, that for the US is always unity $\left(E_{U S}=1\right)$.

\section{Calibration of international financial flow determinants}

The key matrix for calibration is $\left[\beta_{i j}\right]$. These elements are readily available, first, by noting that only relative values are required and hence, for each region of origin, $i$, one value can be set to unity, and second, by making the assumption that the initial database has the steady state property that the net rates of return in regions $\mathrm{j}$ are initially the same as the market bond yield, $r_{j}$. Then, since in the base data $r_{i j}^{e 0}=r_{j}^{0}, r_{i k}^{e 0}=r_{k}^{0}$, the $\beta_{i j}$ s are available from (A9).

\section{Shocking or restricting the global pattern of financial flows}

Some applications require that at least some international financial flows to be exogenous. In a Chinese recession, for example, it is very likely that foreign reserves would be repatriated and that this would significantly alter the flows between China and both the US and EU. A means is therefore required by which the parameters determining bilateral flows can be shocked to represent such effects. It turns out that this is readily done by rendering particular 
shares, $i_{i j}^{S}$, exogenous in the model closure, while the corresponding parameters, $\beta_{i j}$, are made endogenous. This removes the necessity to calculate the shocks to the $\beta_{i j}$ s that would lead to target shifts in the flows.

\section{A2: The Non-Financial Model Components}

The supply side

Although each region supplies a unique differentiated product, production is assumed to draw on a combination of intermediate inputs comprising the home product and imports of products supplied abroad. This allows the capture of differences between the international effects of a policy change in one large country that are due to the dependence of smaller countries on the supply of inputs on the one hand or final products on the other.

The central production technology is expressed in Cobb-Douglas form because total factor productivity and factor shares are readily observed and hence parameterised. Output and factor inputs are included as relative to initial levels so that shocks to productivity or factor shares do not imply changes in initial output volumes, thus facilitating the subsequent decomposition of technology shocks as between productivity and factor or input bias.

In region i gross output volume, $y_{i}$, is a Cobb-Douglas composite of real value added, $v_{i}$, and of intermediates, $q_{i}$.

(A16) $\frac{y_{i}}{y_{i}^{0}}=\left(\frac{A_{i}^{Y}}{A_{i}^{Y 0}}\right)\left(\frac{v_{i}}{v_{i}^{0}}\right)^{\beta_{i}^{V}}\left(\frac{q_{i}}{q_{i}^{0}}\right)^{\left(1-\beta_{i}^{V}\right)}, \forall i, i \in($ regions $)$,

where $A^{Y}$ is total (factor and input) productivity. Value added, in turn, has Cobb-Douglas dependence on domestic primary factors, raw labour, $L$, skill, $S$ and physical capital, $K$.

(A17) $\frac{v_{i}}{v_{i}^{0}}=\left(\frac{A_{i}^{V}}{A_{i}^{V 0}}\right)\left(\frac{L_{i}}{L_{i}^{0}}\right)^{\beta_{i}^{L}}\left(\frac{S_{i}}{S_{i}^{0}}\right)^{\beta_{i}^{S}}\left(\frac{K_{i}}{K_{i}^{0}}\right)^{\beta_{i}^{K}}, \sum_{f} \beta_{i}^{f}=1, \forall i, f \in($ factors $)$.

To allow for inter-regional substitution in intermediate demand across regional sources, domestically employed intermediate inputs, $q$, are a CES composite of products acquired from all regions: 
(A18) $q_{i}=\left(\sum_{j} \alpha_{i j}^{Q} q_{i j}^{-\theta_{i}^{Q}}\right)^{-\frac{1}{\theta_{i}^{Q}}}, \forall i$,

where $q_{i j}$ is the quantity of region $j$ 's product that is absorbed by production in region $i$.

The composite prices of value added and intermediate inputs from (A16) depend on their marginal products:

(A19) $\frac{P_{i}^{V}}{P_{i}^{P}}=\beta_{i}^{V} \frac{y_{i}}{v_{i}}, \frac{P_{i}^{Q}}{P_{i}^{P}}=\left(1-\beta_{i}^{V}\right) \frac{y_{i}}{q_{i}}, \forall i$.

The real production wages of unskilled and skilled workers and the capital rental rate depend conventionally on the corresponding marginal products, from (A16) and (A17).

$$
\begin{aligned}
& w_{i}=\frac{W_{i}}{P_{i}^{P}}=M P_{i}^{L}=\beta_{i}^{V} \beta_{i}^{L} \frac{y_{i}}{L_{i}}, \quad w_{i}^{S}=\frac{W_{i}^{S}}{P_{i}^{P}}=M P_{i}^{S}=\beta_{i}^{V} \beta_{i}^{S} \frac{y_{i}}{S_{i}}, \\
& \frac{R_{i}^{R}}{P_{i}^{P}}=M P_{i}^{K}=\beta_{i}^{V} \beta_{i}^{K} \frac{y_{i}}{K_{i}}, \forall i
\end{aligned}
$$

Here the upper case, $W$, and the lower case $w$, signify nominal and real wage values, and $R^{R}$ is the nominal capital rental rate. $P_{i}^{P}$ is the producer price level - the factory gate price of region $i$ 's product.

The gross volume of output, $y$, is distinguished from real GDP, which is that portion of output that meets final demand, excluding intermediate use, and which equates to real value added, $v$ in (A16). The complete set of demands facing country $i$ 's industries, which must sum to equate with (A16), takes the form:

(A21) $y_{i}=\frac{I_{i}+G_{i}}{P_{i}^{P}}+\sum_{j} c_{j i}+\sum_{j} q_{j i}$,

which is a real version of the standard expenditure identity (on the homogeneous domestic output of region $i$ ) with intermediate demand included. $I$ and $G$ are nominal gross investment and nominal government spending net of transfers, $c_{j i}$ is the volume of final consumption of region $i$ 's product in region $j$, and $q_{j i}$ is the volume of region $i$ 's product that is absorbed as intermediate inputs by production in region $j$. Real GDP omits the final term. Equating this with (A16) determines producer price levels, $P^{P}$, in each region. Producer cost minimisation at these prices then determines the factor rewards indicated in (A19). 


\section{The GDP price, $P^{Y}$}

The revenues from both direct and indirect taxes, $T^{D}$ and $T^{I}$, play key roles in the formulation. Total nominal expenditure on GDP is $Y$ and GDP at factor cost (or at producer's prices) is $Y^{F C}$, which is the total of direct payments to the collective household in return for the use of its factors, equating to $P^{V} v$, where $P^{V}$ is the price of value added. Region $i$ 's nominal GDP is then

$$
Y_{i}=P_{i}^{Y} v_{i}=Y_{i}^{F C}+T_{i}^{I}=P_{i}^{V} v_{i}+T_{i}^{I}
$$

The GDP price would be the same as the producer price, $P^{P}$, were it not for intermediate use and indirect taxes. In their presence we have, from (A20), that:

$$
P_{i}^{Y}=P_{i}^{V}+\frac{T_{i}^{I}}{v_{i}}
$$

Producers in region i choose $v_{i}$ and $q_{i}$ to minimise their total cost, $P_{i}^{P} y_{i}=P_{i}^{V} v_{i}+\hat{P}_{i}^{Q} q_{i}$, where $\hat{P}_{i}^{Q}$ is region $i$ 's CES composite price of intermediates drawn from all regions. Because (A16) is Cobb-Douglas, the value added share of total expenditure by firms on factors and inputs is just $\beta_{i}^{V}=\left(P_{i}^{V} v_{i}\right) /\left(P_{i}^{P} y_{i}\right)$. Substituting in (A23) for $P^{V}$ we have the GDP price in terms of the producer price: ${ }^{39}$

$$
P_{i}^{Y}=\beta_{i}^{V} \frac{y_{i}}{v_{i}} P_{i}^{P}+\frac{T_{i}^{I}}{v_{i}}
$$

\section{Factor and household incomes}

Income from capital is already specified in (1). This is the level of income, after tax, that accrues to the capital-owning household in each region. Households, $h$, are factor-specific, so $h \in(L, S, K)$, with low-skill worker income $Y_{i}^{L}=W_{i} L_{i}$, skilled income $Y_{i}^{S}=W_{i}^{S} S_{i}$ and capital income net of depreciation $Y_{i}^{K N}=\left(1-t_{i}^{K}\right) K_{i}\left(P_{i}^{P} M P_{i}^{K}-P_{i}^{K} \delta_{i}\right)$.

\section{Direct tax}

Constant marginal direct tax rates, $t^{W}, t^{S}$ and $t^{K}$, apply to all labour, skill and net capital

\footnotetext{
39 To calibrate the initial database units are chosen so that the GDP price levels in all regions and nominal exchange rates between them are all initially unity. This implies that $P^{V}=P^{P}$ and that the value added share is $\beta_{i}^{V}=v_{i}^{0} / y_{i}^{0}$.
} 
income, respectively. The corresponding “powers” of these rates are $\tau^{L}=\left(1+t^{L}\right)$, $\tau^{S}=\left(1+t^{S}\right)$ and $\tau^{K}=\left(1+t^{K}\right)$ and so, bearing in mind that taxation of capital income is after depreciation (1), total direct tax revenue is:

(A25) $T_{i}^{D}=t_{i}^{L} W_{i} L_{i}+t_{i}^{S} W_{i}^{S} S_{i}+t_{i}^{K} K_{i}\left(P_{i}^{P} M P_{i}^{K}-P_{i}^{K} \delta_{i}\right)$.

Indirect tax revenue, $T^{I}$, depends on consumption and so it will emerge later.

\section{Household disposable income}

Disposable income, for each household, takes the form:

$$
\begin{aligned}
Y_{h i}^{D}= & s_{h i}^{L}\left[\left(1-t_{i}^{L}\right) W_{i} L_{i}+\alpha_{i} W_{i}^{o}\left(F_{i}-L_{i}\right)\right]+s_{h i}^{S}\left(1-t_{i}^{S}\right) W_{i}^{S} S_{i}^{K} \\
& +s_{h i}^{K}\left(1-t_{i}^{K}\right) K_{i}\left(P_{i}^{P} M P_{i}^{K}-P_{i}^{K} \delta_{i}\right)+T_{h i}^{R}, \quad \forall h
\end{aligned}
$$

where $T_{h}^{R}=t_{h}^{R} N_{h} Y$ is a direct transfer to the household from government revenue, with $t_{h}^{R}$ the transfer rate to household $h$ per unit of group population, $N_{h}$, and per unit of nominal GDP. $^{40}$ Total disposable income is the sum of $Y_{h}^{D}$ across households, which is also GDP at factor cost (household primary income) less total direct taxes, plus net transfers from the government to households and the unemployed: $Y^{D}=\sum_{h} Y_{h}^{D}=Y^{F C}-T^{D}+T^{R}+\alpha W_{0}(F-L)$. Since, from (A20), GDP at factor cost is full GDP less net indirect tax revenue, this can be written as

(A27) $Y^{D}=Y-T^{I}-T^{D}+T^{R}+\alpha W_{0}(F-L)$.

where total regional transfers are $T_{i}^{R}=\sum_{h} T_{h i}^{R}$.

For each household, $h$, in region $i$, consumption expenditure, $C_{h i}$, is a nominal sum but real consumption behaviour is motivated by current and expected future real, per capita, disposable incomes and the real interest rate. Real consumption, (lower case) $c_{h i}$, depends negatively on the after-tax real return on savings (the home bond yield, $r$ ) and positively on both current and expected future real disposable income per capita for that household:

$$
c_{h i}=\frac{C_{h i}}{P_{i}^{C}}=N_{i}^{h} A_{h i}^{C}\left(\frac{r_{i}}{\tau_{i}^{h}}\right)^{-\varepsilon_{h i}^{C R}}\left(\frac{Y_{h i}^{D}}{N_{i}^{h} P_{i}^{C}}\right)^{\varepsilon_{h i}^{C Y}}\left(\frac{Y_{h i}^{D e}}{N_{i}^{h} P_{i}^{C}\left[1+\pi_{h i}^{C e}\right]}\right)^{\varepsilon_{h i}^{C Y}},
$$

\footnotetext{
${ }^{40}$ The expression (A24) is more complex if the labour force participation rates, as defined in (6), of low skill workers, $\lambda_{L h}$, are unequal across households and, similarly, if participation rates of skilled workers, $\lambda_{S h}$, are unequal across households. The simpler expression is offered here since this is not the case in this analysis. The participation rates within skill groups and across households are kept equal in the experiments conducted, although the rates differ between skill groups and may be differently shocked.
} 
where the tax rate on interest income, $\tau^{h}$, is household specific, set as the tax rate on the households dominant source of direct factor income. The expected inflation rate of the consumer price level is $\pi^{c e}$. The elasticities in this expression vary by household, ensuring different consumption responses.

\section{Consumption driven trade and composite pricing}

To capture the home household's substitution between home and foreign products, real aggregate consumption in region $i$ is a CES composite of region $i$ 's consumption of products from all regions:

(A29) $c_{i}=\left(\sum_{j} \alpha_{i j}^{C} c_{i j}^{-\theta_{i}^{C}}\right)^{-\frac{1}{\theta_{i}^{C}}}$

The home household then chooses its mix of consumed products to minimise consumption expenditure in a way that accounts for home consumption and trade taxes, foreign export taxes, differing foreign product prices and exchange rates:

(A30) $C_{i}=P_{i}^{C} c_{i}=P_{i}^{P} \tau_{i}^{C} c_{i i}+\sum_{j \neq i} \tau_{i}^{C} \tau_{i}^{M} \tau_{j}^{X} c_{i j} P_{j}^{P} \frac{E_{j}}{E_{i}}$

where $\tau_{i}^{C}$ is the power of region $i$ 's consumption tax.

Optimum consumption is consistent with an elasticity of substitution between home and Given these consumption volumes, the composite price of all consumption, or the consumer price level, emerges from the combination of (A26) and (A27) in (A28) as:

$$
P_{i}^{C}=\tau_{i}^{C}\left[\left(\alpha_{i i}^{C}\right)^{\sigma_{i}^{C}}\left(P_{i}^{P}\right)^{1-\sigma_{i}^{C}}+\tau_{i}^{M} \sum_{j \neq i}\left(\alpha_{i j}^{C}\right)^{\sigma_{i}^{C}}\left\{\frac{P_{j}^{P} E_{j}}{E_{i}}\right\}^{1-\sigma_{i}^{C}}\right]^{\frac{1}{1-\sigma_{i}^{C}}}
$$

\section{Private saving}

Households receive factor incomes amounting to GDP at factor cost, $Y^{F C}$. Their disposal of nominal income is this sum less direct tax, net of transfers to households and the unemployed (A26). Private saving differs across households. It is what remains after consumption expenditure (gross of indirect taxes) is further deducted from disposable income.

(A32) $S^{P}=\sum_{h}\left[Y_{h}^{D}-C_{h}\right]$. 
Since total consumption expenditure, inclusive of consumption tax, is

(A33) $C=\sum_{h} C_{h}=P^{C} \sum_{h} c_{h}=P^{P} \tau_{C} \sum_{h} c_{h}$,

And total disposable income is from (A26), aggregate private saving can also be written as:

(A34) $S^{P}=Y^{D}-C=\left[Y-T^{I}-T^{D}+T^{R}+\alpha W_{0}(F-L)\right]-C$.

\section{Indirect tax revenue}

This includes revenue from consumption, import and export taxes:

(A35) $T_{i}^{C}=t_{i}^{C}\left(P_{i}^{P} c_{i i}+\sum_{j \neq i} \tau_{i}^{M} \tau_{j}^{X} c_{i j} P_{j}^{P} \frac{E_{j}}{E_{i}}\right)$

(A36) $T_{i}^{M}=t_{i}^{M} M_{i}, \quad M_{i j}=P_{j}^{P} \tau_{j}^{X}\left(q_{i j}+c_{i j}\right) \frac{E_{j}}{E_{i}}, \quad M_{i}=\sum_{j \neq i} M_{i j}$,

(A37) $T_{i}^{X}=t_{i}^{X} X_{i}, \quad X_{i j}=P_{i}^{P} \tau_{i}^{X}\left(q_{j i}+c_{j i}\right), \quad X_{i}=\sum_{j \neq i} X_{i j}$,

(A38) $T_{i}^{I}=T_{i}^{C}+T_{i}^{M}+T_{i}^{X}, \quad T_{i}=T_{i}^{D}+T_{i}^{I}$.

\section{Government and total domestic saving}

This is government revenue from direct taxes, indirect taxes and seigniorage, less government expenditure, both measured net of direct transfers. To simplify the demand side, spending by the government on goods and services, $G^{X}$, is assumed to be directed only at home goods. It pays no taxes and so this expenditure faces the home producer price $P^{P}$.

(A39) $S_{i}^{G}=T_{i}-G_{i}, \quad T_{i}=T_{i}^{D}+T_{i}^{I}+\Delta M_{i}^{B}, \quad G_{i}=T_{i}^{R}+G_{i}^{X}+\alpha_{i} W_{i}^{0}\left(F_{i}-L_{i}\right)$

Total domestic saving is therefore:

(A40) $S_{i}^{D}=S_{i}^{P}+S_{i}^{G}=Y_{i}+\Delta M_{i}^{B}-C_{i}-G_{i}^{X}$.

\section{Intermediate input demand}

To capture region $i$ 's home firms' substitution between intermediate inputs sourced from home and abroad, real aggregate input use, $q_{i}$, is a CES composite of intermediate demands for products from all regions (A18). Home firms then choose their mix of intermediate products to minimise expenditure in a way that accounts for home indirect tax rates, foreign export taxes and differing foreign product prices and exchange rates: 
(41) $V_{i}^{Q}=\hat{P}_{i}^{Q} q_{i}=P_{i}^{P} y_{i}-P_{i}^{V} v_{i}=P_{i}^{P} q_{i i}+\sum_{j \neq i} \tau_{i}^{M} \tau_{j}^{X} q_{i j} P_{j}^{P} \frac{E_{j}}{E_{i}}$,

where $\tau_{i}^{M}$ and $\tau_{j}^{X}$ are, respectively, the powers of region $i$ 's import tax and the region of origin, $j$ 's export tax. Consumption taxes are not levied on intermediate input use. $E_{i}$ is region $i$ 's nominal exchange rate, measured as US\$ per unit of home currency. ${ }^{41}$

Optimum intermediate use is consistent with an elasticity of substitution between home and foreign products of $\sigma_{i}^{Q}=1 /\left(1+\theta_{i}^{Q}\right)$. The corresponding derived demands are then:

Given these volumes, the composite price of all intermediates in region $i, \hat{P}_{i}^{Q}$, emerges from the combination of (A18) and (A41) as:

$$
\hat{P}_{i}^{Q}=\frac{1}{A_{i}^{Q}}\left[\left(\alpha_{i i}^{Q}\right)^{\sigma_{i}^{Q}}\left(P_{i}^{P}\right)^{1-\sigma_{i}^{Q}}+\tau_{i}^{M} \sum_{j \neq i}\left(\alpha_{i j}^{Q}\right)^{\sigma_{i}^{Q}}\left\{\frac{P_{j}^{P} E_{j}}{E_{i}}\right\}^{1-\sigma_{i}^{Q}}\right]^{\frac{1}{1-\sigma_{i}^{Q}}}
$$

\section{Real exchange rate}

Each region has a real exchange rate relative to the US that is the rate of exchange between regional product bundles. With the regions specified as single product economies this measure parallels the terms of trade. Both real and nominal exchange rates are expressed according to the financial convention, so that an appreciation is a rise in value.

(A43) $e_{i}^{U S}=\frac{P_{i}^{Y}}{\left(\frac{P_{U S}^{Y}}{E_{i}}\right)}=E_{i}^{U S} \frac{P_{i}^{Y}}{P_{U S}^{Y}}$.

\section{Exports and Imports}

These are evaluated regionally and bilaterally. Regional totals are single subscripted. Region $i$ 's exports comprise bilateral flows of consumption goods as well as flows of intermediate inputs, priced at the home producer price and marked up by the power of the home export tax:

(A44) $X_{i}=\sum_{i \neq j} X_{i j}, \quad X_{i j}=\sum_{i \neq j}\left(c_{j i}+q_{j i}\right) P_{i}^{P} \tau_{i}^{X}$

\footnotetext{
${ }^{41}$ The US\$ is the numeraire in the model, so $E_{U S}=1$.
} 
Region $i$ 's imports also comprise final demand and intermediate flows, priced at the producer price of the region of origin, marked up by the power of that region's export tax and converted to home currency by the appropriate cross rate.

(A45) $M_{j}=\sum_{i \neq j} M_{i j}, \quad M_{i j}=\sum_{i \neq j}\left(c_{j i}+q_{j i}\right) P_{i}^{P} \tau_{i}^{X} \frac{E_{i}}{E_{j}}$

\section{Effective exchange rates}

Real and nominal effective exchange rates are trade-weighted averages of bilateral rates.

These assist with the interpretation of the results considering that all the bilateral nominal rates are defined relative to the US\$.

$$
e_{i}^{e}=\frac{\sum_{j \neq i}\left[\left(\frac{X_{i j}}{P_{i}^{P} \tau_{i}^{X}}+\frac{M_{i j}}{\tau_{j}^{X} P_{j}^{P} E_{j} / E_{i}}\right) e_{i j}\right]}{\sum_{j \neq i}\left(\frac{X_{i j}}{P_{i}^{P} \tau_{i}^{X}}+\frac{M_{i j}}{\tau_{j}^{X} P_{j}^{P} E_{j} / E_{i}}\right)}, \quad E_{i}^{e}=\frac{\sum_{j \neq i}\left(X_{i j}+M_{i j}\right) E_{i j}}{\sum_{j \neq i}\left(X_{i j}+M_{i j}\right)} .
$$

Welfare and inequality

For distributional analysis, the shares of disposable income and the population shares are then

$$
s_{h i}^{Y D}=Y_{h i}^{D} / Y_{i}^{D}, \quad s_{h i}^{N}=N_{i}^{h} / \sum_{h}^{H} N_{i}^{h}, \quad \forall h \in(L h, S h, K h) .
$$

Our measure of group welfare is real disposable income at consumer prices, $V_{h}=Y_{h}^{D} / P_{C}$ and a three-group Gini coefficient is calculated, first by calculating the area under the threehousehold Lorenz curve:

(A48) $A_{i}^{L}=0.5\left[s_{L h i}^{N} s_{L h i}^{Y D}+s_{S h i}^{N}\left(2 s_{L h i}^{Y D}+s_{S h i}^{Y D}\right)+s_{K h i}^{N}\left(1+s_{L h i}^{Y D}+s_{S h i}^{Y D}\right)\right]$,

and the corresponding Gini coefficient is then

(A49) $G_{i}^{C}=2\left(0.5-A_{i}^{L}\right)$.

\section{A3: The Database and Parameters}

The model database is built on national accounts, international trade and financial data for the global economy in 2011. The relative sizes of the four major economic regions, the US, the EU, Japan and China are indicated in Table A1, from which it is clear that China's economy (even measured without PPP adjustment) is not the smallest of them and it matches the 
largest in investment, exports and saving. The structures of the regional economies are indicated in Table A2. They differ in important ways. The US has a high consumption share of GDP, China a low one. Necessarily, then, the US has a low saving share while China has a high one. Some regions are more dependent on indirect taxes than others, which makes a difference to the proportion of GDP made up of factor cost and hence the size of the household budget and the gap between producer and GDP prices. The EU is relatively dependent on indirect taxes, for example. Since these taxes (at least those accounted for in the model) fall most heavily on consumption, changes in saving behaviour have strong implications for fiscal deficits and, indirectly, for interest premia. Investment is larger in some than in others, being extraordinarily high in China. And then, of course there are the fiscal deficits that are largest in the US and Japan, and the current account surpluses or capital-financial account deficits in Japan and China, at least partly funding the very substantial deficit in the US.

Interactions between these large economies through trade are captured in the consumption expenditure matrix shown in Table A3. It is derived from the combination of national accounts with a matrix of trade flows. The flows are expenditures inclusive of indirect taxes, converted into the shares of total expenditure on goods and services by each country. Implicit, and consistent with the one-good per region model, is the assumption that investment and government spending make demands on the markets for home goods only. As it turns out, this assumption has important implications for the representation of China in the model. Since its consumption is comparatively low and its investment high, home products are mostly absorbed by investment and government spending and so China's consumption is distributed more evenly across regional goods than for the other economies. This suggests a case for an import-dependent capital goods industry in the model.

A complete list of the behavioural parameters used in the model is provided in Table A1. Policy variables in the model are listed in Table A2 and closure choices that determine which are exogenous and can be shocked are indicated in Table A3. The financial interactions between the regions are indicated by the saving-to-investment flows in Table A4. These show the expected Feldstein-Horioka (1980) behaviour but also that there are substantial financial interactions between the US, the EU, Japan and China, in particular. The share of excess saving directed to the US might be expected to change due to the recent decline in reserve accumulation by China and its substitution with outward FDI that, most recently, has not been directed to the US (Tyers et al. 2013). The flows implied by the model database 
system of payments for financial assets and goods and services are then summarised in

Tables A5-A8.

Table A1: Parameters

\begin{tabular}{|c|c|c|c|c|c|c|}
\hline & US & $\mathrm{EU}(26)$ & Japan & China & Australia & RoW \\
\hline \multicolumn{7}{|l|}{ Production shares $^{\mathrm{a}}$} \\
\hline Value added, $\beta^{V}$ & 0.67 & 0.67 & 0.67 & 0.67 & 0.67 & 0.67 \\
\hline Intermediates, $\left(1-\beta^{V}\right)$ & 0.33 & 0.33 & 0.33 & 0.33 & 0.33 & 0.33 \\
\hline \multicolumn{7}{|l|}{ Value added shares } \\
\hline Labour, $\beta^{L}$ & 0.18 & 0.18 & 0.18 & 0.26 & 0.18 & 0.24 \\
\hline Skill, $\beta^{S}$ & 0.47 & 0.47 & 0.47 & 0.24 & 0.47 & 0.21 \\
\hline Capital, $\beta^{K}$ & 0.35 & 0.35 & 0.35 & 0.50 & 0.35 & 0.55 \\
\hline \multicolumn{7}{|l|}{ Income tax rates ${ }^{\mathrm{b}}$} \\
\hline$t^{L}=t^{S}=t^{K}$ & 0.02 & 0.02 & 0.13 & 0.04 & 0.10 & 0.07 \\
\hline \multicolumn{7}{|l|}{ Indirect tax rates ${ }^{c}$} \\
\hline$t^{C}$ & 0.20 & 0.40 & 0.05 & 0.20 & 0.10 & 0.15 \\
\hline$t^{M}$ & 0.15 & 0.43 & 0.11 & 0.19 & 0.11 & 0.31 \\
\hline$t^{X}$ & 0.00 & 0.00 & 0.00 & 0.00 & 0.00 & 0.00 \\
\hline \multicolumn{7}{|l|}{ Money parameters ${ }^{\mathrm{d}}$} \\
\hline Reserve ratio, $\rho$ & 0.05 & 0.05 & 0.05 & 0.15 & 0.05 & 0.10 \\
\hline Cash ratio, $\mu$ & 0.08 & 0.10 & 0.17 & 0.21 & 0.10 & 0.20 \\
\hline \multicolumn{7}{|l|}{ Elasticities } \\
\hline$c$ to $r, \varepsilon^{C R}$ & 0.10 & 0.10 & 0.10 & 0.10 & 0.10 & 0.10 \\
\hline$c$ to $Y^{D}, \varepsilon^{C Y}$ Low income & 1.25 & 1.34 & 1.03 & 1.09 & 1.28 & 1.10 \\
\hline$c$ to $Y^{D}, \varepsilon^{C Y}$ Skilled & 0.90 & 0.99 & 0.79 & 0.89 & 1.00 & 0.84 \\
\hline$c$ to $Y^{D}, \varepsilon^{C Y}$ Capital owning & 0.80 & 0.88 & 0.70 & 0.79 & 0.90 & 0.75 \\
\hline Investment, $I_{i}$ to $r_{i}^{C} / r_{i}, \varepsilon_{i}^{I}$ & 1.00 & 1.00 & 1.00 & 1.00 & 1.00 & 1.00 \\
\hline Premium to $G / T, \phi_{i}$ & 0.20 & 0.20 & 0.20 & 0.20 & 0.20 & 0.20 \\
\hline$m^{D}$ to $y, \varepsilon^{M Y}$ & 0.60 & 0.60 & 0.60 & 0.60 & 0.60 & 0.60 \\
\hline$m^{D}$ to $w^{F}, \varepsilon^{M F}$ & 0.40 & 0.40 & 0.40 & 0.40 & 0.40 & 0.40 \\
\hline$m^{D}$ to $\left(r+\pi^{e}\right),-\varepsilon^{M R}$ & 0.60 & 0.60 & 0.60 & 0.60 & 0.60 & 0.60 \\
\hline \multicolumn{7}{|l|}{ Elasticities of substitution } \\
\hline Factors-inputs, $V A_{i}, / Q_{i}, \sigma_{i}^{V}$ & 1.00 & 1.00 & 1.00 & 1.00 & 1.00 & 1.00 \\
\hline Factors, $L_{i}, S_{i}, K_{i}, \sigma_{i}^{f}$ & 1.00 & 1.00 & 1.00 & 1.00 & 1.00 & 1.00 \\
\hline Consn, $c_{i j} / c_{i k}$ to $P_{i j}^{C} / P_{i k}^{C}, \sigma_{i}^{C}$ & 2.00 & 2.00 & 2.00 & 2.00 & 2.00 & 2.00 \\
\hline Inputs, $q_{i j} / q_{i k}$ to $P_{i j}^{Q} / P_{i k}^{Q}, \sigma_{i}^{Q}$ & 0.90 & 0.90 & 0.90 & 0.90 & 0.90 & 0.90 \\
\hline Saving $i_{i j}^{S} / i_{i k}^{S}$ to $r_{i} / r_{j}, \sigma_{i}^{I}$ & 15.0 & 15.0 & 15.0 & 5.0 & 15.0 & 5.0 \\
\hline
\end{tabular}

a Production shares are based on demographic and occupational data from Tyers et al. (2017), as well as estimates of factor incomes and capital stocks from the GTAP Database.

b These income tax rates are lower than observed because direct transfers and sovereign debt service are deducted from income tax revenue so that observed fiscal balances are consistent with T-G, where G includes only expenditure on goods and services.

c Although export taxes appear in the modelling, no values are applied since such taxes are usually very indirect. To infer the rates for other indirect taxes, approximate rates are initially chosen for the consumption tax rate and the import tax rate is then determined for consistency with the data on indirect tax revenue. In regions where other indirect taxes are major contributors to revenue, this tends to inflate the values of $\mathrm{t}^{\mathrm{C}}$ and $\mathrm{t}^{\mathrm{M}}$. $\mathrm{d}$ The money parameters are crude characterisations, made on the assumption that the EU behaves as if it had a single central bank to cover all 26 members. Money demand parameters stem from a survey of estimates used in other models (including McKibbin and Wilcoxen 1995, Knell and Stix, 2006 and Teles and Zhou 2005). e Consumption elasticities and elasticities of substitution are central among a variety of estimates in use in other models (including McKibbin and Wilcoxen 1995 and Jin 2011). 
Table A2: Exogenous Variables for Experimentation

\begin{tabular}{lll}
\hline Policy & Instrument & \\
\hline Tax rates & Labour income tax & $t_{L}$ \\
& Capital income tax & $t_{K}$ \\
& Consumption tax (GST) & $t_{C}$ \\
& Import tariff & $t_{M}$ \\
& Export tax & $t_{X}$ \\
Fiscal policy & Government spending, US\$ trillion & $G$ \\
& fiscal surplus, US\$ trillion & $S_{G}$ \\
Monetary policy & Monetary base, US\$ trillion & $M_{B}$ \\
& Reserve to deposit ratio & $\rho$ \\
Expectations over future values & Consumer price inflation rate & $\pi^{C e}$ \\
& GDP price inflation rate & $\pi^{Y e}$ \\
& Real exchange rate appreciation & $\hat{e}^{e}$ \\
& Nominal disposable income & $Y_{D}{ }^{e}$ \\
Saving & Rate of return on installed capital & $r_{C}{ }^{e}$ \\
Technical change ${ }^{\mathrm{a}}$ & & \\
& Consumption preference shifters & $A^{C}$ \\
& & \\
& Productivity of all factors and inputs & $A^{Y}$ \\
& Total factor productivity & $A^{V}$ \\
& Bias toward value added from inputs & $\beta^{V}$ \\
& toward labour & $\beta^{L}$ \\
& toward skill & $\beta^{S}$ \\
& toward capital & $\beta^{K}$ \\
\hline
\end{tabular}

a Bias shocks are readily implemented since they do not alter the original levels of output and the database structure, due to the relative formulation of production functions (A15) and (A16).

Table A3: Closure Choices and Policy Regimes

\begin{tabular}{lll}
\hline & $\begin{array}{l}\text { In each case, holding fixed or } \\
\text { exogenous one of: }\end{array}$ & \\
\hline Labour market & $\begin{array}{l}\text { Nominal wage } \\
\text { Labour use }\end{array}$ & $W$ \\
Government & Nominal expenditure & $L$ \\
& Fiscal surplus & $G$ \\
& Monetary base & $S_{G}=T-G$ \\
Monetary target & Consumer price level & $M_{B}$ \\
& GDP price level & $P^{C}$ \\
& Producer price level & $P^{Y}$ \\
& Exchange rate & $P^{P}$ \\
& & $E$ \\
\hline
\end{tabular}


Table A4: Relative Economic Sizes of China and the Other Large Regions, ca 2011

\begin{tabular}{lllll}
\hline \multicolumn{1}{c}{ \% of world } & China & US & EU(26) & Japan \\
\hline GDP & 11 & 22 & 26 & 9 \\
Consumption, $C$ & 8 & 27 & 26 & 9 \\
Investment, $I$ & 20 & 15 & 22 & 8 \\
Government spending, $G$ & 7 & 20 & 30 & 10 \\
Exports, $X$ & 17 & 17 & 25 & 7 \\
Imports, $M$ & 15 & 21 & 23 & 8 \\
Total domestic saving, $S^{D}$ & 19 & 13 & 20 & 9 \\
\hline
\end{tabular}

Sources: National accounts data supply most of the elements though adjustments have been required to ensure that current accounts sum to zero globally, as do capital/financial accounts. The IMF-IFS database is the major source but there is frequent resort to national statistical databases.

Table A5: Regional Economic Structure, 2011

\begin{tabular}{ccccccc}
\hline \multicolumn{1}{c}{ \% of GDP } & US & EU(28) & Japan & China & Australia & RoW \\
\hline$C$ & 0.712 & 0.580 & 0.605 & 0.450 & 0.536 & 0.550 \\
$I$ & 0.155 & 0.191 & 0.200 & 0.410 & 0.275 & 0.240 \\
$G$ & 0.171 & 0.217 & 0.204 & 0.114 & 0.177 & 0.199 \\
$X$ & 0.139 & 0.175 & 0.151 & 0.285 & 0.217 & 0.200 \\
$M$ & 0.177 & 0.163 & 0.161 & 0.259 & 0.204 & 0.189 \\
Indirect tax rev, $T^{I}$ & 0.144 & 0.235 & 0.047 & 0.125 & 0.070 & 0.130 \\
Direct tax rev, $T^{D}$ & 0.017 & 0.015 & 0.124 & 0.035 & 0.093 & 0.061 \\
Total tax rev, $T$ & 0.161 & 0.250 & 0.171 & 0.160 & 0.163 & 0.191 \\
Private saving, $S^{P}$ & 0.127 & 0.169 & 0.224 & 0.390 & 0.301 & 0.259 \\
Govt saving, $S^{G}$ & -0.010 & 0.034 & -0.034 & 0.046 & -0.013 & -0.008 \\
Total saving, $S^{D}$ & 0.155 & 0.191 & 0.200 & 0.410 & 0.275 & 0.240 \\
Monetary base, $M^{B}$ & 0.133 & 0.114 & 0.220 & 0.411 & 0.134 & 0.250 \\
Capital stock, $K$ & 3.317 & 3.414 & 4.239 & 2.740 & 4.027 & 2.000 \\
\hline
\end{tabular}

Sources: National accounts data supply most of the elements though adjustments have been required to ensure that current accounts sum to zero globally, as do capital/financial accounts. The IMF-IFS database is the major source but there is frequent resort to national statistical databases.

Table A6: Shares of Total Domestic Saving Directed to Investment in each Region, $2011^{\mathrm{a}}$

\begin{tabular}{lcccccc}
\hline $\begin{array}{l}\text { \% of row total } \\
\text { saving }\end{array}$ & US & EU(28) & Japan & China & Australia & RoW \\
\hline US $^{\mathrm{b}}$ & 68.0 & 13.3 & 6.4 & 6.4 & 1.5 & 4.4 \\
$\mathrm{EU}(26)^{\mathrm{c}}$ & 12.9 & 80.1 & 2.3 & 2.3 & 0.9 & 1.5 \\
$\mathrm{Japan}^{\mathrm{d}}$ & 14.0 & 3.3 & 72.2 & 6.2 & 0.7 & 3.6 \\
China $^{\mathrm{c}}$ & 9.2 & 0.6 & 0.9 & 81.1 & 0.1 & 8.0 \\
Australia $^{\mathrm{e}}$ & 13.0 & 4.8 & 2.3 & 2.1 & 77.3 & 0.4 \\
Rest of world & 3.4 & 3.9 & 2.6 & 2.8 & 0.1 & 87.2 \\
\hline
\end{tabular}

a These shares sum to 100 horizontally. They are based on 2011 investment flows. The original flow matrix is inconsistent with data on saving and investment from national accounts and so a RAS algorithm is used to ensure that row and column sums are consistent with other data. The row sums of the flow matrix are total saving by region and the column sums are total investment by region. These sums are sourced from the IMFIFS database and the World Bank database.

b USA: values are based on official statistics, BEA.

c EU and China: indirect information from USA, Australian and Japanese statistics.

d Japan: estimated based on FDI data, assuming investment outflow=FDI*1.6. The ratio 1.6 is that of USA reported inward investment from Japan divided by Japanese reported outward FDI to the USA.

e Australia: Australian Bureau of Statistics "International Investment Position, Australia: Supplementary Statistics, 2011".

$\mathrm{f}$ ROW is a residual. Its saving is inferred from national accounts estimates and its investment abroad is determined to balance the matrix of financial flows. 
Table A7: Shares of Consumption of final Goods by Region of Origin, 2011

\begin{tabular}{lcccccc}
\hline $\begin{array}{l}\text { \% of row } \\
\begin{array}{l}\text { consn } \\
\text { expenditure }\end{array}\end{array}$ & US & EU(28) & Japan & China & Australia & RoW \\
\hline US & 82.5 & 6.0 & 1.6 & 2.4 & 0.4 & 7.2 \\
EU(26) & 6.3 & 74.5 & 1.8 & 4.0 & 0.4 & 13.0 \\
Japan & 2.8 & 3.5 & 84.6 & 2.6 & 0.5 & 6.1 \\
China & 10.9 & 19.1 & 11.7 & 42.7 & 0.6 & 15.0 \\
Australia & 7.1 & 11.3 & 3.3 & 8.1 & 60.4 & 9.8 \\
Rest of world & 12.5 & 19.2 & 3.4 & 9.2 & 0.3 & 55.4 \\
\hline
\end{tabular}

a These shares sum to 100 horizontally. They are based on the 2011 matrix of trade flows combined with consumption expenditure data in each region. The resulting matrix is inconsistent as between data sources and so a RAS algorithm is used to force consistency of bilateral elements with national accounts data.

Sources: Implied trade flows are for 2011, drawn from the World Trade Organisation database.

Table A8: Use Shares of Intermediate Goods by Region of Origin, 2011

\begin{tabular}{lcccccc}
\hline $\begin{array}{l}\text { \% of row } \\
\text { intermediate } \\
\text { expenditure }\end{array}$ & US & EU(28) & Japan & China & Australia & RoW \\
\hline US & 79.0 & 5.4 & 0.9 & 4.8 & 0.2 & 9.7 \\
EU(26) & 4.3 & 75.4 & 0.8 & 6.1 & 0.2 & 13.3 \\
Japan & 2.2 & 1.8 & 81.9 & 4.6 & 2.2 & 7.3 \\
China & 1.7 & 3.0 & 1.9 & 67.8 & 3.4 & 22.2 \\
Australia & 0.8 & 1.3 & 0.4 & 0.9 & 94.1 & 2.5 \\
Rest of world & 1.5 & 2.3 & 0.4 & 1.1 & 0.8 & 93.9 \\
\hline
\end{tabular}

a These shares sum to 100 horizontally. They are based on the 2011 matrix of trade flows combined with intermediate use expenditure data in each region. The raw matrix of consumption plus intermediate use flows is inconsistent as between data sources and so a RAS algorithm is used to force consistency of bilateral elements with national accounts data.

Sources: Implied trade flows are for 2011, drawn from the World Trade Organisation database. 


\section{Appendix References:}

Feldstein, M. and C.Y. Horioka (1980), "Domestic Saving and International Capital Flows," Economic Journal, Royal Economic Society, 90(358): 314-29, June.

Jin, Y. (2011), “Income inequality, consumption and social-status seeking”, Journal of Comparative Economics, 39:191-204.

Johnson, R.S., R.A. Zuber and J.M. Gandar (2010), “A re-examination of the market segmentation theory as a pedagogical model”, Journal of Financial Education, 36(1/2): 1-37, Spring/Summer.

Knell, M. and H. Stix (2006), "Three decades of money demand studies: differences and similarities”, Applied Economics, 38(7): 805-818.

McKibbin, W.J. and P. Wilcoxen (1995), "The theoretical and empirical structure of the GCubed model”, Economic Modelling, Elsevier, 16(1): 123-148, January.

Teles, P. and R. Zhou (2005), “A stable money demand: Looking for the right monetary aggregate”, Economic Perspectives, Federal Reserve Bank of Chicago, Q I: 50-63.

Tyers, R., Y. Zhang and T.S. Cheong (2013), “China’s saving and global economic performance”, Chapter 6 in Garnaut, R., F. Cai and L. Song (eds,) China: A New Model for Growth and Development, Canberra: ANU E Press and Beijing: Social Sciences Academic Press, Pp 97-124; http://epress.anu.edu.au/titles/china-updateseries/china-a-new-model-for-growth-and-development. 
Editor, UWA Economics Discussion Papers:

Sam Hak Kan Tang

University of Western Australia

35 Sterling Hwy

Crawley WA 6009

Australia

Email: ecoadmin@biz.uwa.edu.au

The Economics Discussion Papers are available at:

1980 - 2002: $\quad$ http://ecompapers.biz.uwa.edu.au/paper/PDF\%20of\%20Discussion\%20Papers/

Since 2001: $\quad$ http://ideas.repec.org/s/uwa/wpaper1.html

Since 2004: $\quad$ http://www.business.uwa.edu.au/school/disciplines/economics

\begin{tabular}{|c|c|c|}
\hline \multicolumn{3}{|c|}{ ECONOMICS DISCUSSION PAPERS - 2016} \\
\hline $\begin{array}{l}\text { DP } \\
\text { NUMBER }\end{array}$ & AUTHORS & TITLE \\
\hline 16.01 & Xu, R., Wu, Y. and Luan, J. & $\begin{array}{l}\text { ANALYSIS OF FARMERS’ WILLINGNESS TO ADOPT } \\
\text { GENETICALLY MODIFIED INSECT-RESISTANT RICE IN } \\
\text { CHINA }\end{array}$ \\
\hline 16.02 & $\begin{array}{l}\text { Lia, Y., Fan, J., Zhao, D., Wu, Y. and } \\
\text { Li, J. }\end{array}$ & $\begin{array}{l}\text { TIERED GASOLINE PRICING: A PERSONAL CARBON } \\
\text { TRADING PERSPECTIVE }\end{array}$ \\
\hline 16.03 & Clements, K.W., Lan, Y. and Si, J. & UNCERTAINTY IN CURRENCY MISPRICING \\
\hline 16.04 & Parsons, C. and Vézina, P.L. & $\begin{array}{l}\text { MIGRANT NETWORKS AND TRADE:THE VIETNAMESE } \\
\text { BOAT PEOPLE AS A NATURAL EXPERIMENT }\end{array}$ \\
\hline 16.05 & Chang, S., Connelly, R. and Ma, P. & $\begin{array}{l}\text { WHAT WILL YOU DO IF I SAY 'I DO’?: THE EFFECT OF } \\
\text { THE SEX RATIO ON TIME USE WITHIN TAIWANESE } \\
\text { MARRIED COUPLES }\end{array}$ \\
\hline 16.06 & Yu, F. and Wu, Y. & $\begin{array}{l}\text { BIASES IN PATENT EXAMINATION AND FIRMS’ } \\
\text { RESPONSES: EVIDENCE FROM THE } \\
\text { PHARMACEUTICAL INDUSTRY }\end{array}$ \\
\hline 16.07 & $\begin{array}{l}\text { Fan, J., Li, J., Wu, Y., Wang, S. and } \\
\text { Zhao, D. }\end{array}$ & $\begin{array}{l}\text { THE EFFECTS OF ALLOWANCE PRICE ON ENERGY } \\
\text { DEMAND UNDER A PERSONAL CARBON TRADING } \\
\text { SCHEME }\end{array}$ \\
\hline 16.08 & Golley, J., Tyers, R. and Zhou, Y. & $\begin{array}{l}\text { CONTRACTIONS IN CHINESE FERTILITY AND } \\
\text { SAVINGS: LONG RUN DOMESTIC AND GLOBAL } \\
\text { IMPLICATIONS }\end{array}$ \\
\hline 16.09 & McGrath, G. and Neill, K. & $\begin{array}{l}\text { FOREIGN AND DOMESTIC OWNERSHIP IN WESTERN } \\
\text { AUSTRALIA'S GAS MARKET }\end{array}$ \\
\hline 16.10 & Clements, K.W. and Si, J. & SIMPLIFYING THE BIG MAC INDEX \\
\hline 16.11 & Priyati, R.Y. and Tyers, R. & $\begin{array}{l}\text { PRICE RELATIONSHIPS IN VEGETABLE OIL AND } \\
\text { ENERGY MARKETS }\end{array}$ \\
\hline 16.12 & Wu, J., Wu, Y. and Wang, B. & $\begin{array}{l}\text { THE GREENNESS OF CHINESE CITIES: CARBON } \\
\text { DIOXIDE EMISSION AND ITS DETERMINANTS }\end{array}$ \\
\hline 16.13 & $\begin{array}{l}\text { Arslan, C., Dumont, J.C., Kone, Z., } \\
\text { Özden, Ç., Parsons, C. and } \\
\text { Xenogiani, T. }\end{array}$ & $\begin{array}{l}\text { INTERNATIONAL MIGRATION TO THE OECD IN THE } \\
\text { TWENTY-FIRST CENTURY }\end{array}$ \\
\hline 16.14 & Tomioka, K. and Tyers, R. & $\begin{array}{l}\text { HAS FOREIGN GROWTH CONTRIBUTED TO } \\
\text { STAGNATION AND INEQUALITY IN JAPAN? }\end{array}$ \\
\hline
\end{tabular}




\begin{tabular}{|c|c|c|}
\hline 16.15 & Donovan, J. and Hartley, P. & $\begin{array}{l}\text { RIDING THE IRON ORE CYCLE: ACTIONS OF } \\
\text { AUSTRALIA'S MAJOR PRODUCERS }\end{array}$ \\
\hline 16.16 & Czaika, M. and Parsons, C. & $\begin{array}{l}\text { HIGH-SKILLED MIGRATION IN TIMES OF GLOBAL } \\
\text { ECONOMIC CRISIS }\end{array}$ \\
\hline 16.17 & Lefroy, T., Key, J. and Kingwell, R. & $\begin{array}{l}\text { A LONGITUDINAL EXAMINATION OF BROADACRE } \\
\text { FARM SIZE AND PERFORMANCE IN WESTERN } \\
\text { AUSTRALIA }\end{array}$ \\
\hline 16.18 & Arthmar, R. and McLure, M. & $\begin{array}{l}\text { SRAFFA, MYRDAL AND THE } 1961 \text { SÖDERSTRÖM GOLD } \\
\text { MEDAL }\end{array}$ \\
\hline 16.19 & Azwar, P. and Tyers, R. & $\begin{array}{l}\text { POST-GFC EXTERNAL SHOCKS AND INDONESIAN } \\
\text { ECONOMIC PERFORMANCE }\end{array}$ \\
\hline 16.20 & Chen, A. and Groenewold, N. & $\begin{array}{l}\text { OUTPUT SHOCKS IN CHINA: DO THE DISTRIBUTIONAL } \\
\text { EFFECTS DEPEND ON THE REGIONAL SOURCE? }\end{array}$ \\
\hline 16.21 & Wu, Y., Zhu, X. and Groenewold, N. & $\begin{array}{l}\text { THE DETERMINANTS AND EFFECTIVENESS OF } \\
\text { INDUSTRIAL POLICY IN CHINA: A STUDY BASED ON } \\
\text { FIVE-YEAR PLANS }\end{array}$ \\
\hline 16.22 & Liu, H. & $\begin{array}{l}\text { THE INCOME AND PRICE SENSITIVITY OF DIETS } \\
\text { GLOBALLY }\end{array}$ \\
\hline 16.23 & Asano, A., Neill, K. and Yamazaki, S. & $\begin{array}{l}\text { DECOMPOSING FISHING EFFORT: MODELLING THE } \\
\text { SOURCES OF INEFFICIENCY IN A LIMITED-ENTRY } \\
\text { FISHERY }\end{array}$ \\
\hline 16.24 & Golley, J., Tyers, R. and Zhou, Y. & $\begin{array}{l}\text { FERTILITY AND SAVINGS CONTRACTIONS IN CHINA: } \\
\text { LONG-RUN GLOBAL IMPLICATIONS }\end{array}$ \\
\hline 16.25 & Taylor, G., Tyers, R. & $\begin{array}{l}\text { SECULAR STAGNATION: DETERMINANTS AND } \\
\text { CONSEQUENCES FOR AUSTRALIA }\end{array}$ \\
\hline
\end{tabular}

\begin{tabular}{|c|c|c|}
\hline \multicolumn{3}{|c|}{ ECONOMICS DISCUSSION PAPERS - 2017} \\
\hline $\begin{array}{l}\text { DP } \\
\text { NUMBER }\end{array}$ & AUTHORS & TITLE \\
\hline 17.01 & Tyers, R. and Zhou, Y. & $\begin{array}{l}\text { AUTOMATION AND INEQUALITY WITH TAXES AND } \\
\text { TRANSFERS }\end{array}$ \\
\hline 17.02 & Ye, L. and Robertson, P. & $\begin{array}{l}\text { HITTING THE GREAT WALL: RURAL-URBAN } \\
\text { MIGRATION AND CHINA'S GROWTH SLOWDOWN }\end{array}$ \\
\hline 17.03 & Ye, L. and Robertson, P. & $\begin{array}{l}\text { MIGRATION AND GROWTH IN CHINA: A SCEPTICAL } \\
\text { ASSESSMENT OF THE EVIDENCE }\end{array}$ \\
\hline 17.04 & Clements, K. Si, J. and Vo, L. & $\begin{array}{l}\text { FOOD AND AGRICULTURAL PRICES ACROSS } \\
\text { COUNTRIES AND THE LAW OF ONE PRICE }\end{array}$ \\
\hline 17.05 & $\begin{array}{l}\text { Chen, M., Clements, K., Gao, G. and } \\
\text { Si, J. }\end{array}$ & THREE FACTS ABOUT WORLD METAL PRICES \\
\hline 17.06 & $\begin{array}{l}\text { Cornes, R., Fiorini, L. and } \\
\text { Maldonado, W. }\end{array}$ & $\begin{array}{l}\text { EXPECTATIONAL STABILITY IN AGGREGATIVE } \\
\text { GAMES }\end{array}$ \\
\hline 17.07 & Hartley, P. & $\begin{array}{l}\text { THE COST OF DISPLACING FOSSIL FUELS: SOME } \\
\text { EVIDENCE FROM TEXAS }\end{array}$ \\
\hline 17.08 & Shehabi, M. R. & ASSESSING KUWAITI ENERGY PRICINING REFORMS \\
\hline 17.09 & Perdana, S. and Tyers, R. & $\begin{array}{l}\text { GLOBAL CLIMATE CHANGE MITIGATION: STRATEGIC } \\
\text { INTERACTION OR UNILATERAL GAINS? }\end{array}$ \\
\hline 17.10 & McLure, M. & $\begin{array}{l}\text { RICARDIAN EQUIVALENCE, THE ITALIAN FISCAL } \\
\text { TRADITION AND WA GOVERNMENT NET DEBT }\end{array}$ \\
\hline 17.11 & Trinh, J. & $\begin{array}{l}\text { THE PARETO DISTRIBUTION AND ITS RELATIONSHIP } \\
\text { TO PIKETTY'S THIRD FUNDAMENTAL LAW OF } \\
\text { CAPITALISM }\end{array}$ \\
\hline
\end{tabular}




\begin{tabular}{|c|c|c|}
\hline 17.12 & McLure, M. & $\begin{array}{l}\text { THINKING OUTSIDE THE BOX: A NEW HISTORY OF } \\
\text { EDGEWORTH'S AND PARENTO'S DEVELOPMENT OF } \\
\text { THE BOX DIAGRAM }\end{array}$ \\
\hline 17.13 & Zhou, Y. and Tyers, R. & AUTOMATION AND INEQUALITY IN CHINA \\
\hline 17.14 & Arthmar, R. and McLure, M. & $\begin{array}{l}\text { THE ECONOMIC AND SOCIAL CONSEQUENCES OF THE } \\
\text { WAR: PIGOU, THE PRESS AND THE STRUGGLE FOR AN } \\
\text { HONOURABLE PEACE }\end{array}$ \\
\hline 17.15 & Shehabi, M. R. & $\begin{array}{l}\text { CONTEMPORARY KUWAITISATION DYNAMICS AND } \\
\text { THEIR HISTORICAL PERSPECTIVES }\end{array}$ \\
\hline 17.16 & Clements, K. and Si, J. & $\begin{array}{l}\text { WHAT DO AUSTRALIAN ECONOMICS PhDs DO? THE } \\
\text { UWA EXPERIENCE }\end{array}$ \\
\hline 17.17 & Arthmar, R. and McLure, M. & KEYNES AND THE ROYAL SWEDISH ACADEMY \\
\hline 17.18 & Chen, A. and Groenewold, N. & $\begin{array}{l}\text { CHINA'S ‘NEW NORMAL’: IS THE GROWTH } \\
\text { SLOWDOWN DEMAND- OR SUPPLY- DRIVEN? }\end{array}$ \\
\hline 17.19 & Groenewold, N. & $\begin{array}{l}\text { CHINA’S ‘NEW NORMAL’: HOW WILL CHINA’S } \\
\text { GROWTH SLOWDOWN AFFECT AUSTRALIA’S } \\
\text { GROWTH? }\end{array}$ \\
\hline
\end{tabular}

\begin{tabular}{|l|l|l|}
\hline \multicolumn{2}{|c|}{ ECONOMICS DISCUSSION PAPERS - 2018 } \\
\hline $\begin{array}{c}|c| \\
\text { DP } \\
\text { NUMBER }\end{array}$ & \multicolumn{1}{|c|}{ AUTHORS } \\
\hline 18.01 & Tyers, R. and Zhou, Y. & TITLE \\
\hline 18.02 & McLure, M. & LOST INFLATION? \\
\hline 18.03 & McLure, M. and Montesano, A. & PARETIAN FISCAL SOCIOLOGY \\
\hline 18.04 & THINKING OUTSIDE THE BOX: EDGEWORTH, PARETO \\
\hline
\end{tabular}

